\title{
Bench to bedside review of myositis autoantibodies
}

\author{
Boaz Palterer ${ }^{*}$ (D), Gianfranco Vitiello, Alessia Carraresi, Maria Grazia Giudizi, Daniele Cammelli \\ and Paola Parronchi
}

\begin{abstract}
Idiopathic inflammatory myopathies represent a heterogeneous group of autoimmune diseases with systemic involvement. Even though numerous specific autoantibodies have been recognized, they have not been included, with the only exception of anti-Jo-1, into the 2017 Classification Criteria, thus perpetuating a clinical-serologic gap. The lack of homogeneous grouping based on the antibody profile deeply impacts the diagnostic approach, therapeutic choices and prognostic stratification of these patients. This review is intended to highlight the comprehensive scenario regarding myositis-related autoantibodies, from the molecular characterization and biological significance to target antigens, from the detection tools, with a special focus on immunofluorescence patterns on HEp-2 cells, to their relative prevalence and ethnic diversity, from the clinical presentation to prognosis. If, on the one hand, a notable body of literature is present, on the other data are fragmented, retrospectively based and collected from small case series, so that they do not sufficiently support the decision-making process (i.e. therapeutic approach) into the clinics.
\end{abstract}

Keywords: Myositis, Autoantibodies, Immunofluorescence, Anti-nuclear antibodies, Dermatomyositis, Polymyositis, Immune-mediated necrotizing myopathy, Inclusion body myositis, MDA5, HMGCR

\section{Background}

The detection of autoantibodies in autoimmune diseases, either systemic or organ specific, can have both diagnostic and prognostic importance. Some autoantibodies have a clear pathogenic role, such as anti-erythrocyte membrane proteins antibodies in autoimmune hemolytic anemia and anti-dsDNA in Systemic Lupus Erythematosus (SLE). However, the presence of autoantibodies is more frequently considered to be an epiphenomenon, even though their detection plays a critical role for the diagnosis of some connective tissue diseases (CTDs), [i.e. anti$\mathrm{SSA} /$ Ro in Sjögren syndrome (SjS) and anti-Sm in SLE], as included into the classification criteria of CTDs $[1,2]$. Repeated serum sampling might be informative about the clinical course of the disease and response to immunosuppressive therapy, as in the case of anti-dsDNA antibodies in SLE. Furthermore, the presence of some autoantibodies could help to discriminate specific clinical

*Correspondence: boaz.palterer@unifi.it

Experimental and Clinical Medicine Department, University of Florence,

Largo Brambilla 3, 50134 Florence, Italy patterns within the same disease, as with diffuse and limited cutaneous systemic sclerosis (SSc) and their relationship with anti-Scl-70 and anti-centromere, respectively.

In idiopathic inflammatory myopathies (IIMs), albeit anti-Jo-1 autoantibody was discovered more than thirty years ago, the percentage of patients in whom an autoantibody could not be recognized (the so called "serologic gap") was still high until recently. IIMs have been historically divided in polymyositis (PM) and dermatomyositis (DM) on a purely clinical basis despite phenotypic variability.

Due to this heterogeneity, the numerous autoantibodies and unavailability of reliable assays in all the laboratories, the clinical use of serology lagged behind and autoantibodies are not part of the most recent IIM Classification Criteria [3].

A comprehensive review regarding the clinical features, diagnostic work-up and relationship to some peculiar autoantibodies has been recently published by Milone [4]. 


\section{Myositis-specific and-associated autoantibodies: definitions}

Autoantibodies found in IIM patients have been classified into two main categories: myositis-specific autoantibodies (MSAs), which can be found in IIMs exclusively, and myositis-associated autoantibodies (MAAs), which can also be found in other CTDs [5, 6]. MSAs and MAAs are summarized in Table 1.

There is no agreement about the attribution of rare and newly discovered autoantibodies to either MSAs or MAAs group [7]. Anti-synthetase autoantibodies (ARS) themselves, especially anti-PL-7, PL-12 and KS, often detected in interstitial pneumonia with autoimmune features (IPAF) patients, independently from muscular involvement, are still discussed as MSAs [8].

The MAAs group contains Anti-Pm-Scl, U1/U2RNP and $\mathrm{Ku}$, which are associated with overlap syndromes with muscular involvement [9]. Anti-fibrillarin and antiU1-snRNP are sometimes considered as MAAs, even though they are more specific for the diagnosis of SSc and mixed connective tissue disease (MCTD), respectively $[10,11]$. Anti-Ro52 are usually considered a MAA, even though they are more frequently found in association with other MSA (ARS, anti-MDA5 and anti-SRP, in particular) [12], and define a peculiar clinical spectrum in which the lung involvement is more common than the muscular one [13].

\section{Detection methods}

There are several methods to test for MSAs and MAAs, with variable sensibility, specificity, costs, complexity and feasibility in clinical and research settings. Indirect immuno-fluorescence (IIF) on $\mathrm{HEp}-2$ cells, counterimmuno-electrophoresis (CIE), immuno-diffusion (ID) and immuno-enzymatic assays such as enzyme-linked immunosorbent assay (ELISA), fluorescent enzymelinked assay (FEIA) and chemiluminescent immunoassay (CLIA) are the most commonly adopted systems in diagnostic laboratories. However, immuno-precipitation (IP) of RNAs with silver staining and/or protein IP of cellular lysates (usually K562 cells) radiolabeled with ${ }^{35} \mathrm{~S}$-methionin, is the gold standard for most antibodies. In order to streamline the detection of many autoantibodies at the same time in a cost/effective manner, recent multiplex assays, like immunoblots (IB) and Addressable Laser Beads Immuno Assay (ALBIA) have been developed [14].

Anti-nuclear autoantibodies (ANA) determination by IIF is virtually universally available and it can be considered an accessible screening method for many MSAs and MAAs [15]. Furthermore, the recognition of particular IIF patterns can hint to some specific autoantibodies. However, using ANA IIF as the sole screening method for MSAs/MAAs, is not recommended because of low sensitivity, very low specificity and/or lack of antigen expression by HEp-2 cells [16]. In addition to this, ANA IIF is burdened by reproducibility issues due to the operator-dependent recognition of rare patterns and variation among different commercial HEp-2 substrates [17].

CIE and ID have historically been the first methods to detect specific MSAs/MAAs. Even though they identify numerous specificities within a single assay, they are semi-quantitative, work-intensive and scarcely sensitive [14]. For all those reasons, they have been largely substituted by immunoenzymatic tests.

The main advantages of ELISAs are standardization, large-scale reproducibility and quantitative results. The disadvantage of the conjugation of antigens to a substrate resides on the possible loss of conformational epitopes and/or the formation of neo-epitopes, which may in turn impact the test performance [14].

Immunoblot (IB) assays can simultaneously test for many autoantibodies, albeit the denaturation of proteins during gel preparation implicates the recognition of linear epitopes only [14].

Commercial multiplex IBs, like dot blots or line blot assays (LIA), based on recombinant or synthetic peptides have been increasingly available, benefitting from pure antigens not requiring a gel passage $[18,19]$.

IP is the gold standard as it evaluates the binding of the autoantibodies to the RNA and protein complexes in their native conformation, yielding the best sensitivity and specificity [20]. The major limitations of IP are due to technical difficulties, costs and use of radioactive reagents [20]. In addition, interpretation may be complex because the target antigen can co-precipitate with non-target complexed proteins, with the consequence of multiple IP bands [20]. Thus, a comparison with reference sera or further purification and characterization with other methods (i.e. mass spectrometry) is necessary [14]. Quantitative PCR of reverse transcribed RNA components extracted from standard IP can be also used as a detection method for autoantibodies binding ribonucleoproteic complexes [21].

\section{Myositis-specific autoantibodies \\ Anti-synthetases autoantibodies}

ARS are a group of autoantibodies directed against the aminoacyl transfer RNA (tRNA) synthetases, which are amino acid-charging enzymes. Autoantibodies to eight tRNA synthetases have been discovered so far: histidyl (Jo-1), threonyl (PL-7), alanyl (PL-12), glycyl (EJ), isoleucyl $(\mathrm{OJ})$, asparaginyl (KS), phenylalanyl (ZO), and tyrosyl (YRS/HA) tRNA synthetases [22].

Anti-Jo-1 antibodies were identified by double immune-diffusion (DID) of calf thymus extract in 1980 
Table 1 Summary of the main features of MSAs and MAAs

\begin{tabular}{|c|c|c|c|c|c|}
\hline \multirow[t]{2}{*}{ Antibody } & \multirow[t]{2}{*}{ Antigen } & \multicolumn{2}{|l|}{ IP } & \multirow{2}{*}{$\begin{array}{l}\text { IIF } \\
\text { HEp-2 }\end{array}$} & \multirow[t]{2}{*}{ Clinical association } \\
\hline & & Proteins (kDa) & RNA & & \\
\hline \multicolumn{6}{|c|}{ Myositis-specific autoantibodies (MSAs) } \\
\hline Anti-Jo-1 & $\begin{array}{l}\text { Histidyl-tRNA syn- } \\
\text { thetase }\end{array}$ & 50 & tRNA ${ }^{\text {His }}$ & $\begin{array}{l}\text { Cytoplasmic fine } \\
\text { speckled }\end{array}$ & $\begin{array}{l}\text { Classic anti-synthetase } \\
\text { syndrome with more } \\
\text { frequent muscle } \\
\text { involvement }\end{array}$ \\
\hline Anti-PL-7 & $\begin{array}{l}\text { Threonyl-tRNA syn- } \\
\text { thetase }\end{array}$ & 80 & tRNA $^{\text {Thr }}$ & $\begin{array}{l}\text { Cytoplasmic dense fine } \\
\text { speckled }\end{array}$ & $\begin{array}{l}\text { Anti-synthetase syn- } \\
\text { drome with prevalent } \\
\text { ILD }\end{array}$ \\
\hline Anti-PL-12 & Alanyl-tRNA synthetase & 110 & tRNA Ala & $\begin{array}{l}\text { Cytoplasmic dense fine } \\
\text { speckled }\end{array}$ & $\begin{array}{l}\text { Anti-synthetase syn- } \\
\text { drome with prevalent } \\
\text { ILD }\end{array}$ \\
\hline Anti-EJ & Glycyl-tRNA synthetase & 75 & tRNA ${ }^{\text {Gly }}$ & Cytoplasmic speckled & $\begin{array}{l}\text { Anti-synthetase syn- } \\
\text { drome }\end{array}$ \\
\hline Anti-OJ & $\begin{array}{l}\text { Isoleucyl-tRNA syn- } \\
\text { thetase }\end{array}$ & $150+170 / 130 / 75$ & tRNA $^{\text {Iso }}$ & Cytoplasmic speckled & $\begin{array}{l}\text { ILD alone or anti-syn- } \\
\text { thetase syndrome }\end{array}$ \\
\hline Anti-KS & $\begin{array}{l}\text { Asparaginyl-tRNA } \\
\text { synthetase }\end{array}$ & 65 & tRNA ${ }^{\text {Asp }}$ & Cytoplasmic speckled & $\begin{array}{l}\text { ILD alone or anti-syn- } \\
\text { thetase syndrome }\end{array}$ \\
\hline Anti-Zo & $\begin{array}{l}\text { Phenylalanyl-tRNA } \\
\text { synthetase }\end{array}$ & $60 / 70$ & tRNA ${ }^{\text {Phe }}$ & Cytoplasmic speckled & Myositis \\
\hline Anti-YRS/HA & Tyrosyl-tRNA synthetase & 59 & $\mathrm{tRNA}^{\mathrm{Tyr}}$ & Cytoplasmic speckled & Myositis \\
\hline Anti-Mi-2 & $\begin{array}{l}\text { Nucleosome Remod- } \\
\text { elling Deacetylase } \\
\text { (NuRD) (Mi-2a/ } \beta \text { ) }\end{array}$ & $240+200 / 150 / 75 / 65 / 63 / 50 / 34$ & & Fine speckled & Classical DM \\
\hline Anti-SAE & $\begin{array}{l}\text { Small ubiquitin-like } \\
\text { modifier activating } \\
\text { enzyme (SAE1/2) }\end{array}$ & $40 / 90$ & & Fine speckled & $\begin{array}{l}\text { Severe cutaneous disease } \\
\text { that classically precede } \\
\text { DM with severe dys- } \\
\text { phagia and systemic } \\
\text { symptoms }\end{array}$ \\
\hline $\begin{array}{l}\text { Anti-MDA5 (anti- } \\
\text { CADM140) }\end{array}$ & $\begin{array}{l}\text { Melanoma Differentia- } \\
\text { tion-Associated gene } \\
5 \text { (MDA5) }\end{array}$ & 140 & & $\begin{array}{l}\text { Negative or Cytoplas- } \\
\text { mic speckled }\end{array}$ & $\begin{array}{l}\text { Hypo-amyopathic, ILD } \\
\text { with possible RP-ILD } \\
\text { and severe and peculiar } \\
\text { skin involvement }\end{array}$ \\
\hline $\begin{array}{l}\text { Anti-TIF1y/a (anti- } \\
\text { p155/p140) }\end{array}$ & $\begin{array}{l}\text { Transcription intermedi- } \\
\text { ary factor } 1 \text { (TIF1 } / \text { /a) }\end{array}$ & $155 / 140$ & & Fine speckled & $\begin{array}{l}\text { Juvenile DM. Cancer- } \\
\text { associated hypo-myo- } \\
\text { pathic DM }\end{array}$ \\
\hline Anti-TIF1 $\beta$ & $\begin{array}{l}\text { Transcription intermedi- } \\
\text { ary factor } 1 \beta\end{array}$ & 120 & & Fine speckled & $\mathrm{DM}$ \\
\hline Anti-NXP2 (anti-MJ) & $\begin{array}{l}\text { Nuclear matrix protein } \\
\text { (NXP-2) }\end{array}$ & 140 & & $\begin{array}{l}\text { Fine speckled and/or } \\
\text { multiple nuclear dots }\end{array}$ & $\begin{array}{l}\text { Juvenile DM, diffused } \\
\text { calcinosis. Cancer- } \\
\text { associated DM }\end{array}$ \\
\hline Anti-SRP & $\begin{array}{l}\text { Signal recognition } \\
\text { particle }\end{array}$ & $72 / 68 / 54 / 19 / 14 / 9$ & $7 S L$ & $\begin{array}{l}\text { Cytoplasmic dense fine } \\
\text { speckled }\end{array}$ & $\begin{array}{l}\text { IMNM with frequent } \\
\text { esophageal involve- } \\
\text { ment. Possible ILD }\end{array}$ \\
\hline Anti-HMGCR & HMG-CoA reductase & $200 / 100$ & & $\begin{array}{l}\text { Negative or Cytoplas- } \\
\text { mic speckled }\end{array}$ & $\begin{array}{l}\text { IMNM with or with- } \\
\text { out history of statin } \\
\text { exposure }\end{array}$ \\
\hline \multicolumn{6}{|c|}{ Myositis-associated autoantibodies(MAAs) } \\
\hline Anti-PM-SCl & $\begin{array}{c}\text { Exosome protein com- } \\
\text { plex (PM/Scl75/100) }\end{array}$ & $75 / 100$ & & $\begin{array}{l}\text { Nucleolar homogene- } \\
\text { ous }\end{array}$ & Overlap PM/SSc \\
\hline Anti-C1D & $\begin{array}{l}\text { Exosome associated } \\
\text { protein }\end{array}$ & & & & Overlap PM/SSC \\
\hline Anti-U1-RNP & U1 small nuclear RNP & $11-70$ & U1 & Coarse speckled & MCTD \\
\hline $\begin{array}{l}\text { Anti-fibrillarin (anti- } \\
\text { U3-snRNP) }\end{array}$ & Fibrillarin & 34 & U3 & Nucleolar clumpy & SSC \\
\hline Anti-Ku & $\begin{array}{l}\text { DNA-PK regulatory } \\
\text { subunit }\end{array}$ & $70 / 80$ & & Fine speckled & $\begin{array}{l}\text { PM/SSc. Potentially } \\
\text { severe ILD }\end{array}$ \\
\hline
\end{tabular}


Table 1 continued

\begin{tabular}{|c|c|c|c|c|c|}
\hline \multirow[t]{2}{*}{ Antibody } & \multirow[t]{2}{*}{ Antigen } & \multicolumn{2}{|l|}{ IP } & \multirow{2}{*}{$\begin{array}{l}\text { IIF } \\
\text { HEp-2 }\end{array}$} & \multirow[t]{2}{*}{ Clinical association } \\
\hline & & Proteins (kDa) & RNA & & \\
\hline Anti-Ro52 & Ro-52/TRIM21 & 52 & & $\begin{array}{l}\text { Negative, fine speckled } \\
\text { or cytoplasmic } \\
\text { speckled }\end{array}$ & $\begin{array}{l}\text { ILD. Frequently coupled } \\
\text { with other MSA }\end{array}$ \\
\hline Anti-Ro60/SSA & Ro-60/SS-A & 60 & & Fine speckled & SjS, SLE \\
\hline Anti-La/SSB & SS-B & 48 & & Fine speckled & SjS, SLE \\
\hline $\begin{array}{l}\text { Anti-cN-1A (anti- } \\
\text { Mup44) }\end{array}$ & $\begin{array}{l}\text { Cytosolic 5'nucleoti- } \\
\text { dase } 1 \mathrm{~A}\end{array}$ & & & & sIBM \\
\hline \multicolumn{6}{|l|}{ Miscellaneous } \\
\hline Anti-RuvBL1/2 & RuvBL1/2 complex & $48 / 49$ & & Speckled & SSC, PM, Morphea \\
\hline Anti-Su/Ago2 & Argonaute 2 & $100 / 102$ and 200 & & $\begin{array}{l}\text { Cytoplasmic discrete } \\
\text { dots }\end{array}$ & $\begin{array}{l}\text { ILD in absence of cancer. } \\
\text { Frequently coupled } \\
\text { with MSA, Ro- } 52 \text { and } \\
\text { other antibodies }\end{array}$ \\
\hline Anti-SMN & $\begin{array}{l}\text { Survival of Motor } \\
\text { Neuron }\end{array}$ & $38+130 / 120 / 33$ & & Few nuclear dots & $\mathrm{PM} / \mathrm{SSC}$ \\
\hline Anti-NUP & $\begin{array}{l}\text { Nup358/RanBP2, gp210, } \\
\text { Nup90, p200/p130, } \\
\text { Nup62 }\end{array}$ & & & $\begin{array}{l}\text { Punctate nuclear } \\
\text { envelope }\end{array}$ & $\begin{array}{l}\text { Subgroup of PM/SSC } \\
\text { patients (so called NUP- } \\
\text { syndrome). PBC }\end{array}$ \\
\hline $\begin{array}{l}\text { Anti-mitochondrial } \\
\text { (AMA-M2) }\end{array}$ & $\begin{array}{l}\text { Branched-chain } \\
\text { a-ketoacid dehydro- } \\
\text { genase complex }\end{array}$ & & & $\begin{array}{l}\text { Cytoplasmic reticular/ } \\
\text { AMA }\end{array}$ & $\begin{array}{l}\text { Long-lasting myositis } \\
\text { with muscle atrophy } \\
\text { and cardiac involve- } \\
\text { ment. PBC }\end{array}$ \\
\hline Anti-KJ & Translocation factor & $30 / 43$ & & Cytoplasmic speckled & $\begin{array}{l}\text { Anti-synthetase-like } \\
\text { syndrome }\end{array}$ \\
\hline Anti-Fer (anti-eEF1) & $\begin{array}{l}\text { Eukaryotic elongation } \\
\text { factor } 1\end{array}$ & & & & $\begin{array}{l}\text { Anti-synthetase-like } \\
\text { syndrome }\end{array}$ \\
\hline Anti-Wa & & 48 & & Cytoplasmic speckled & $\begin{array}{l}\text { Anti-synthetase-like } \\
\text { syndrome }\end{array}$ \\
\hline Anti-Mas & $\begin{array}{l}\text { selenocysteine seryl- } \\
\text { tRNA-protein complex }\end{array}$ & 48 & tRNA ${ }^{[\mathrm{Ser}] \mathrm{Sec}}$ & Cytoplasmic speckled & $\begin{array}{l}\text { Non-immune mediated } \\
\text { rhabdomyolysis. Auto- } \\
\text { immune hepatitis }\end{array}$ \\
\hline Anti-PMS & $\begin{array}{l}\text { DNA repair mismatch } \\
\text { enzyme (PMS1, PMS2, } \\
\text { MLH1) }\end{array}$ & & & & Mild myositis \\
\hline Anti-cortactin & Cortactin & 68 & & & PM. Myasthenia gravis \\
\hline Anti-FHL1 & $\begin{array}{l}\text { Four-and-a-Half LIM } \\
\text { domain } 1\end{array}$ & & & & $\begin{array}{l}\text { Myositis and muscular } \\
\text { atrophy with severe } \\
\text { systemic involvement }\end{array}$ \\
\hline
\end{tabular}

and were the first MSAs described [23]. IP represents the gold standard for their identification with the following protein bands: Jo-1 50 kDa, PL-7 80 kDa, PL-12 110 kDa, EJ $75 \mathrm{kDa}$, OJ $150 \mathrm{kDa}$ and a multi-enzyme complex of 170,130 , and $75 \mathrm{kDa}$, KS $65 \mathrm{kDa}, \mathrm{ZO} 60 / 70 \mathrm{kDa}, \mathrm{YRS} /$ HA $59 \mathrm{kDa}[22]$.

IIF on HEp-2 cells usually demonstrates a cytoplasmic pattern, ranging from fine (Jo-1) to dense fine speckled or homogeneous (PL-7, PL-12) whereas the nucleoplasm is usually negative (Fig. 1a-e) [24]. In these cases, also patients without muscular involvement should be assessed for ARS especially when interstitial lung disease (ILD), arthritis or scleroderma features are present [25].
Anti-Jo-1 is the only autoantibody routinely tested as widely available in most commercial ENA screening assays. An ELISA screening test has been recently developed to identify ARS, with high sensibility and specificity if compared to IP [26] and some commercially available IBs can identify some non-Jo-1 anti-synthetase antibodies $[20,25]$.

Anti-Jo-1 was first discovered in the '80ies in patients with PM [23]. Larger cohorts later demonstrated that its presence was associated with the classical triad of arthritis, myositis and ILD in the majority of patients, in addition to Raynaud's phenomenon, mechanic's hands and fever. This clinical presentation together with anti-Jo-1 autoantibodies, led to the description of the 


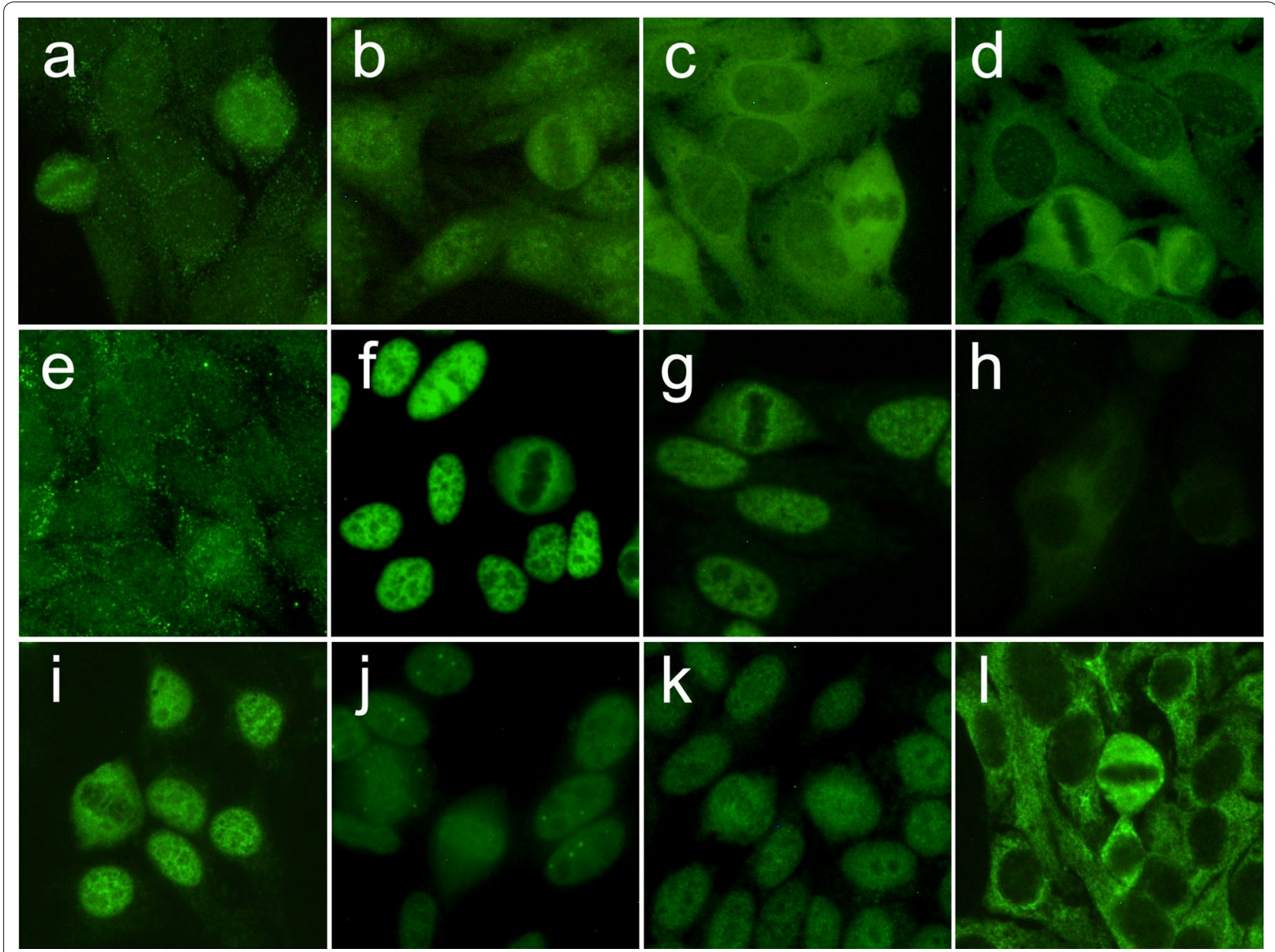

Fig. 1 IIF on HEp-2 ANA slides of myositis-specific autoantibodies from patients with IIMs (EUROIMMUN, Lübeck, Germany). a Anti-Jo-1 and b anti-Jo-1 and anti-Ro52, $\mathbf{c}$ anti-PL-7, $\mathbf{d}$ anti-PL-12, e anti-KS, $\mathbf{f}$ anti-Mi-2, $\mathbf{g}$ anti-SAE-1, $\mathbf{h}$ anti-MDA5, $\mathbf{i}$ anti-NXP-2 and $\mathbf{j}$ anti-NXP-2 with coiled bodies, $\mathbf{k}$ anti-TIF1Y, I anti-SRP

antisynthetase syndrome (ASSD), the first attempt to phenotype IIMs in clinical-serologic syndromes [27]. Anti-Jo-1 is detected in $15-25 \%$ of patients with polymyositis/dermatomyositis $(\mathrm{PM} / \mathrm{DM})$, whereas the other ARS are rarer (anti-PL-7 4-12\%, PL-12 < 5\%, EJ $<5 \%$, $\mathrm{OJ}<5 \%$ and only few cases reported with anti-KS, ZO e HA/YRS) [22]. In two-third of the cases, high titers of anti-Ro52 antibodies can be also detected and have been associated with an higher risk of ILD [28].

Clinically, anti-PL-7 patients more frequently present hypo-myopathic features $[29,30]$, whereas in anti-PL-12 and anti-KS patients the disease can be limited to the lung [31-33]. In a quarter of anti-Jo-1 patients, a symmetrical polyarthritis mimicking rheumatoid arthritis is the main presenting finding and, in some of them, anticyclic citrullinated peptide antibodies and rheumatoid factors can be also detected [34].
Regardless of clinical characteristics at presentation (arthritis, myositis and ILD) every patient tends to develop the other features of ASSD when not properly treated [34]. Of note, the lower esophageal sphincter is involved more frequently if compared to the other IIMs [35]. ASSD is histopathologically classified within perimysial immune-myopathies in which perimysium fragmentation and muscle fiber necrosis are the main feature, differently from other DM biopsically characterized by atrophy and vasculopathy [36]. Type I interferon-signature in ASSD is responsible for MHC class I upregulation [37] and MHC class II perifascicular expression [38].

\section{Anti-Mi-2}

Anti-Mi-2 antibodies were the first autoantibodies specific for DM recognized by DID using calf thymus extract [39]. Mi-2 is a helicase of the Nucleosome Remodeling 
Deacetylase (NuRD) multi-protein complex with nucleosome remodeling and histone deacetylase/demethylase activities [40]. Anti-Mi-2 autoantibodies immunoprecipitate a major protein of $240 \mathrm{kDa}$, composed by two proteins, Mi- $2 \alpha$ and Mi- $2 \beta$ of 220 and $218 \mathrm{kDa}$, respectively. Other NuRD complex proteins co-precipitate at $200,150,75,65,63,50$ and $34 \mathrm{kDa}[41,42]$. IIF on HEp-2 cells reveals a characteristic fine speckled ANA pattern; during metaphase, chromatin mass is not stained but the nucleoplasm presents the same fine tiny speckles (Fig. 1f). Commercial ELISA and immunoblot kits identify anti-Mi-2 autoantibodies. Anti-Mi-2 are commonly detected in DM patients, either in adults (11-59\%) or in children (4-10\%), with a great variability among the studies. Their presence in PM and sporadic inclusion body myositis (sIBM) is rarer [40].

The Mi-2 protein is over-regulated during muscle regeneration in DM patients and thought to be related to UV rays exposition, sex and HLA (DRB1*0302 and DRB1*0701) [43-45]. Anti-Mi-2 positive DM patients usually exhibit mild myopathy despite high creatine kinase (CK) levels, without lung involvement and/or cancer [43]. Overall, anti-Mi2 positive is associated with a positive prognosis and a good response to corticosteroids [43].

\section{Anti-SAE}

Small Ubiquitin-like Modifiers (SUMOs) have a key role in post-transcriptional modification of specific proteins in a ubiquitin-like fashion. This process is controlled by the SUMO-Activating Enzyme (SAE), a heterodimer composed of two subunits, SAE-1 and SAE-2 [46], representing the targets of anti-SAE autoantibodies. IP characteristically shows two bands of 40 and $90 \mathrm{kDa}$, respectively [46, 47]. The IIF ANA pattern is coarse or fine speckled and nucleoli are typically not stained (Fig. 1g) [47].

Anti-SAE are associated with a typical DM phenotype with different prevalence in European (4-10\%) and Asian (1-3\%) cohorts [48-50], probably due to the strict association with HLADRB1"04-DQA1*03-DQB1"03 haplotypes [51].

The cutaneous involvement is usually severe and typically precedes the muscular involvement. Other clinical relationships cannot be excluded because of the few described cases. However, ILD seems to be rare, whereas severe dysphagia and systemic symptoms have been reported [47]. Only one case series claimed an association with cancer [52].

\section{Anti-MDA5}

Melanoma Differentiation-Associated gene 5 (MDA5) or Interferon-induced helicase $\mathrm{C}$ domain-containing protein 1 (IFIH1), is an innate cytosolic sensor, member of the retinoic acid-inducible gene I (RIG-I)-like receptors family (RLRs). MDA5 is able to recognize doublestranded RNA and to initiate signaling events leading to type I interferons production [53].

Anti-MDA5 autoantibodies were firstly detected in IP as a $140 \mathrm{kDa}$ band in a Japanese case series of patients with clinically amyopathic dermatomyositis (CADM) and rapidly progressive interstitial lung disease (RP-ILD). For this reason, they were initially called anti-CADM-140 autoantibodies [54]. Nowadays, ELISA and IB tests are commercially available.

IIF on HEp-2 cells is usually negative. In our experience, a faint fine speckled cytoplasmic fluorescence may be detected in scattered cells (unpublished data) (Fig. 1h).

Clinically, DM anti-MDA5 positive patients present low grade/absent muscle inflammation and acute or subacute RP-ILD $[55,56]$, which is considered the major negative prognostic factor of this subgroup [57].

MDA5 represents the most frequent target antigen in DM patients of Asian ancestry (10-48\% of cases) [58] whereas its prevalence in Europe and USA ranges from 0 to $13 \%$, with great variability among the studies [59-61] and a different clinical presentation. A forthcoming European case series is going to be presented at the European League Against Rheumatism 2018 Congress by Cavagna et al. (unpublished data). A seasonal pattern of CADM has been proposed by Muro et al. [62], suggesting the influence of environmental factors and HLA-DRB1*04:01 and "12:02 have been proposed as further predisposing factors [63].

In addition to classic DM-related cutaneous manifestations, skin involvement is usually severe and characterized by the so called "inverse Gottron papules", which are tender palmar papules that tend to evolve towards ulcerated-necrotic lesions, with or without digital pulp ulcers $[64,65]$. In addition, polyarthritis, recurrent oral aphtosis and diffuse alopecia have been described [66]. A juvenile DM with anti-MDA5 autoantibodies has been also described [67]. No association with malignancies has been demonstrated so far. Macrophage activation syndrome have been described in CADM associated RP-ILD patients. Particularly, a ferritin level of above $1500 \mathrm{ng} / \mathrm{mL}$ has been claimed as a predictor of death [68, 69]. AntiMDA5 autoantibodies titer seems to correlate with disease activity and response to therapy [69].

\section{Anti-TIF-1}

The transcription intermediary factors-1 (TIF-1) family belongs to the tripartite motif-containing proteins (TRIM) superfamily and is involved in multiple biological processes, such as cycle regulation, mitosis and innate immunity [70]. 
Targoff et al. and Kaji et al. [71, 72] independently described two antibodies directed against a 155 and $140 \mathrm{kDa}$, rapidly identified as TIF-1Y (TRIM33) and TIF-1 $\alpha$ (TRIM24), respectively. Subsequently, a third $120 \mathrm{kDa}$ band, partially overlapping with anti-PL-12, was identified as TIF1 $\beta$ (TRIM28) [73].

IIF on HEp-2 cells demonstrates a fine speckled nuclear pattern (Fig. 1i). ELISA and IB, compared to IP, are reliable test for the detection of anti-TIF- $1 \gamma$ autoantibod-

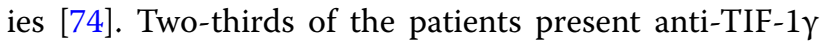
and anti-TIF- $1 \alpha$ autoantibodies, whereas the remaining one-third is positive for anti-TIF-1 $\gamma$ autoantibodies exclusively [70]. Albeit MSAs are claimed to be mutually exclusive, double-positive patients for anti-TIF- $1 \alpha / \mathrm{Mi}-2$ autoantibodies have been described [75].

Hyper-expression of TIF-1 $\gamma$ has been found in tumors [76] and regenerating myofibres of DM patients [77]. A meta-analysis demonstrated that anti-TIF- $1 \gamma$ has a $78 \%$ sensitivity and $89 \%$ specificity for the diagnosis of cancerassociated myositis, with a $58 \%$ positive and $95 \%$ negative predictive value [78]. The risk of malignancy is higher in patients with anti-TIF- $1 \gamma / \alpha$ than in those with antiTIF-1 $\gamma$ alone [70].

Clinically, anti-TIF-1 positive patients can be classified in two age groups: (1) younger than 40-year-old patients, with a classical DM at presentation and (2) older than 40-year-old patients, with cancer-associated myositis [70]. Solid tumors, like ovary, lung and breast cancer are the most commonly associated neoplasia, but hematologic disorders and malignancies have been described as well [79]. In general anti-TIF-1 $\gamma$ patients exhibit a hypomyopathic DM with reduced prevalence of systemic involvement, namely ILD, Raynaud's phenomenon and arthritis [80]. Conversely, nutcracker esophagus is three times more frequent in anti-TIF- $1 \gamma$ patients than other IIMs [35]. Widespread cutaneous involvement is associated with unique features, such as palmar hyper-keratotic papules, psoriatic-like dermatitis and atrophic hypo-pigmented patches with telangiectasias [80]. An ovoid palatal patch may be present in about one half of patients, more frequently females with cancer-associated amyopathic disease [81].

\section{Anti-NXP-2}

Nuclear matrix protein 2 (NXP-2), encoded by the microrchidia 3 gene, is a $140 \mathrm{kDa}$ protein involved in epigenetic regulation, RNA metabolism and preservation of nuclear chromatin architecture [82]. Anti-NXP-2 autoantibodies were found in a cohort of juvenile DM patients as a $140 \mathrm{kDa}$ protein firstly named anti-MJ [83].

IIF on HEp-2 cells reveals a fine speckled nuclear pattern (Fig. 1k). Moreover, a nuclear dots pattern is detectable in $60 \%$ of sera [84], due to co-localization of NXP-2 with pro-myelocitic leukemia (PML) bodies [85] (Fig. 1j).

Anti-NXP-2 antibodies have been initially associated with a severe juvenile DM complicated by calcinosis, polyarthritis and intestinal vasculitis [86]. More recently, they have been also found in adult patients, with variable prevalence from 1.6 to 17\% [87-89]. Anti-NXP-2 autoantibodies show a bimodal spectrum of clinical association, with calcinosis being more frequent in younger patients and cancer more common in the elderly [90], especially in male gender [88], even though with a lower prevalence when compared to anti-TIF-1 $[87,88]$.

\section{Anti-SRP}

The signal recognition particle (SRP) is a complex of six proteins $(9,14,19,54,68$ and $72 \mathrm{kDa})$ and a 300 nucleotides long RNA (7SL RNA) involved in the recognition and transportation of proteins to the endoplasmic reticulum [91]. Anti-SRP autoantibodies are more frequently directed against the SRP-54 fragment, albeit anti-SRP-68, anti-SRP-72 and anti-7SL RNA autoantibodies have been also described [91].

A dense fine speckled cytoplasmic pattern has been associated with the presence of anti-SRP (Fig. 2a); moreover, IIF on stomach-liver-kidney rat sections demonstrates a cytoplasmic staining of gastric chief cells (Fig. 2b) and hepatocytes (Fig. 2c) [92].

Anti-SRP-54 autoantibodies ELISA tests are commercially available, but they are less sensitive than IP [93]. Anti-SRP antibodies can also be tested on LIA assays, however careful temperature control is necessary in order to avoid false positive results [19].

These autoantibodies are strongly associated with immune-mediated necrotizing myositis (IMNM) where they may play a pathogenic role [94]. Histopathologically, they are characterized by scarce inflammatory CD8+ endomysial infiltrate, class I MHC upregulation, necrosis and myofiber regeneration [36] with poor response to therapy, mimicking muscular dystrophy [95]. Being strongly associated to HLA-DR5, the prevalence of antiSRP autoantibodies is higher in Asian (8-13\%) than in European patients [96]. Prevalence of anti-SRP in IMNM is highly variable among studies, ranging from 0 to $54 \%$, because of differences regarding the type of assay (IB vs IP), low number of patients and genetic background [97-100]. In addition, esophageal involvement is common [101], whereas the possibility of a prominent cardiac involvement has not been yet confirmed [99, 102]. Lung involvement has been reported in a few cases [103], as well as an overlap with anti-synthetase antibodies like PL-12 and anti-Jo-1 [104, 105]. Intriguingly, 


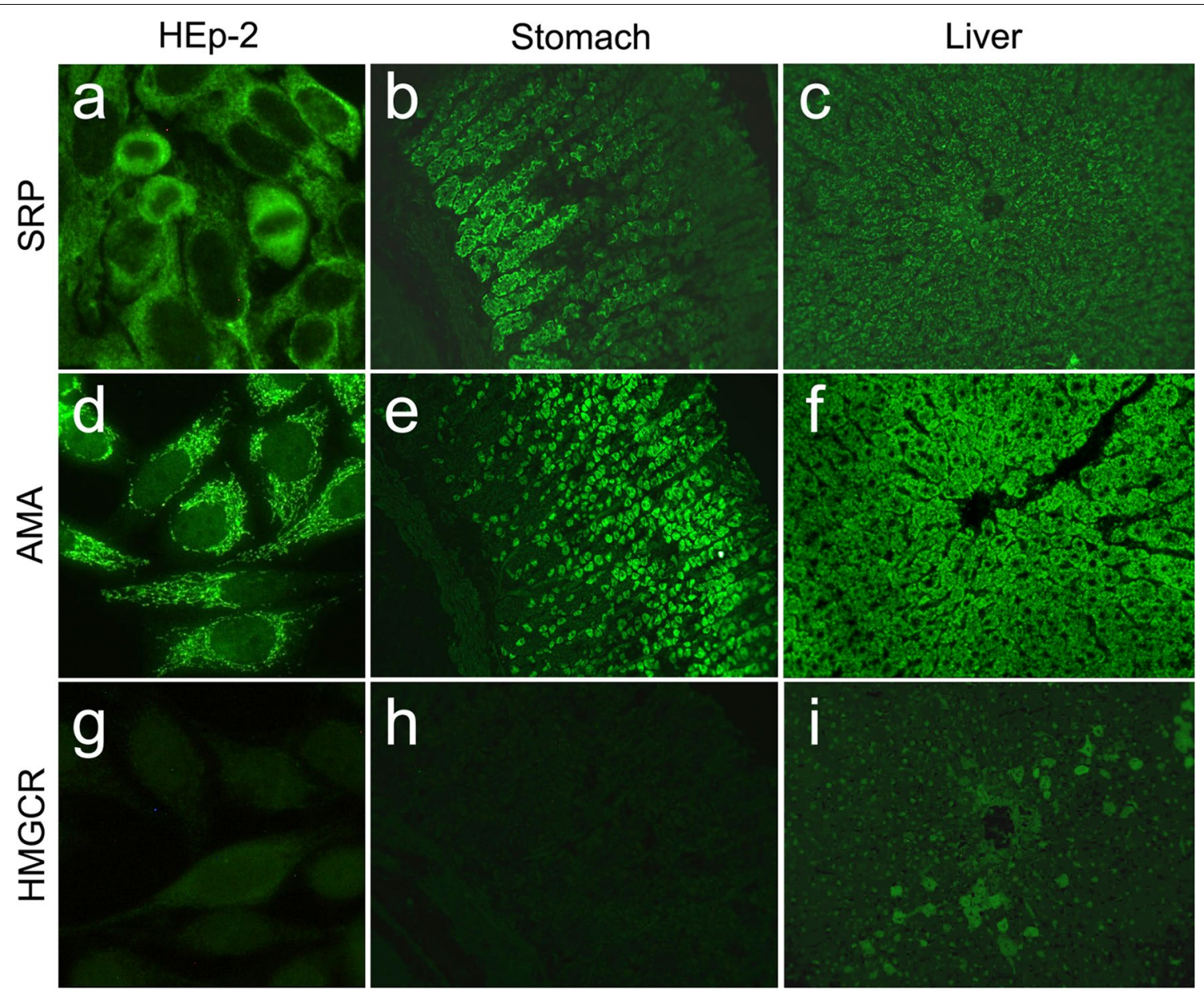

Fig. 2 Immunofluorescence patterns from patients with IMNMs with anti-SRP and anti-HMGCR antibodies on HEp-2 ANA slides (EUROIMMUN, Lübeck, Germany) and rat liver and stomach slides (DiaSorin, Italy), compared to AMA-M2 antibodies. a Anti-SRP cytoplasmic dense fine speckled pattern on HEp-2, b chief cells on stomach and $\mathbf{c}$ fine granular liver staining; d AMA-M2 cytoplasmic reticular on HEp-2, e granular staining of parietal stomach cells and $\mathbf{f}$ diffused fluorescence of hepatocytes; $\mathbf{g}$ Anti-HMGCR faint cytoplasmic fluorescence on few numbers of HEp-2 cells, $\mathbf{h}$ negative stomach and $\mathbf{i}$ fine cytoplasmic fluorescence of scattered hepatocytes around the biliary ducts

autoantibodies level correlates to disease activity, CK levels and response to therapy [106].

\section{Anti-HMGCR}

The 3-hydroxy-3-methylglutaryl-coenzyme A reductase (HMGCR) is the rate-controlling enzyme of the mevalonate pathway, bringing to the production of cholesterol. Of note, HMGCR is the same enzyme targeted by statins. Autoantibodies towards a complex 200/100 kDa band were first described in patients with IMNM, and only after identified as anti-HMGCR autoantibodies [107].

IIF pattern is difficult to recognize. In a minority of cases finely granular cytoplasmic staining with a perinuclear reinforcement is visible on a small number of scattered cells (3\% of the total cellularity) (Fig. $2 \mathrm{~g}$ ). On rat liver, a scattered cytoplasmic staining of hepatocytes around the liver lobules, namely anti-HMGCR Antibody Associated Liver Immunofluorescence Pattern (HALIP), can be noted (Fig. 2i) [108, 109]. Anti-HMGCR antibodies can be identified with different immunoenzymatic technologies, such as ELISA, CLIA, IB or ALBIA [110].

A history of statin exposure is not mandatory to develop anti-HMGCR positive IMNM, being of some relevance only in patients older than $50[111,112]$. AntiHMGCR antibodies are not found in self-limiting statin associated myopathy [113], albeit they may be associated with an increased risk of cancer [114]. An association with the DRB1*11:01 haplotype has been demonstrated, whereas DQA1 and DQB1 seem to have a protective role [115].

Anti-HMGCR positive patients present with a typical IMNM, responds well to immunosuppressive therapy 
and intravenous immunoglobulins [116], but tend to relapse after tapering [111]. Younger patients experience more severe disease with worse prognosis [117]. Autoantibody titers seem to correlate with CK levels, muscular weakness and response to therapy [111].

\section{Myositis-associated autoantibodies}

Numerous MAAs have been described so far. Characteristically, they can be found in IIMs, albeit not specific as found in other CTDs [118].

\section{Anti-PM-Scl}

Anti-PM-Scl autoantibodies are directed against the exosome, a macromolecular nucleolar complex composed by $11-16$ proteins (from 20 to $110 \mathrm{kDa}$ ) that degrades mRNA. The two pivotal proteins of the complex are PMScl-75 and PM-Scl-100. IP represents the gold standard for their determination. Historically, an ID test after positive nucleolar staining in IIF was used to confirm antiPM-Scl reactivity.

PM-Scl-100 and PM-Scl-75 were identified in 1992 and, in the following years, the immuno-dominant epitope PM1 $\alpha$ was cloned and employed to develop reliable and specific ELISA tests [119]. PM1 $\alpha$ ELISA and PM-Scl-100 LIA tests show concordance with IP at high level $(>90$ and 98.3\%, respectively), whereas PM-Scl-75 LIA has a lower specificity, especially when considering PM/ SSc overlap syndromes [120]. Single positivity against
PM-Scl-75 or -100 can be detected and associates with different disease phenotypes. HEp-2 IIF typically shows a mixed homogeneous nucleolar and fine speckled nuclear pattern when anti-PM-Scl-100 are present, whilst antiPM1- $\alpha$ and PM-Scl-75 may show both nucleolar and non-nucleolar patterns (Fig. 3a, b).

PM-Scl autoantibodies are found in $4-12 \%$ of adult patients with myositis $[121,122]$ with low prevalence in Asiatic and paediatric cohorts [123]. Their presence has been associated with HLA-DQA1*0501, DQB1*02 and DRB1*0301 alleles [122].

Despite their presence in many connective tissue diseases, these autoantibodies are typically present in $\mathrm{PM} / \mathrm{SSc}$ overlap syndromes with an increased risk of Raynaud's phenomenon, arthritis, mechanic's hands and ILD [124]. In detail, isolated anti-PM-Scl-75 have been more frequently found in patients with joint contractures and SSc, higher CK levels associate with anti-PM-Scl-100, whereas the simultaneous presence of anti-PM-Scl-75 and -100 are linked to muscle involvement, digital ulcers and ILD but lower prevalence of lung hypertension [125].

Autoantibodies directed against C1D, an exosome associated protein, were detected by ELISA and Western blot analysis in $23 \%$ of a PM/SSc overlap syndrome cohort, with frequencies comparable to anti-PM/Scl antibodies [126].

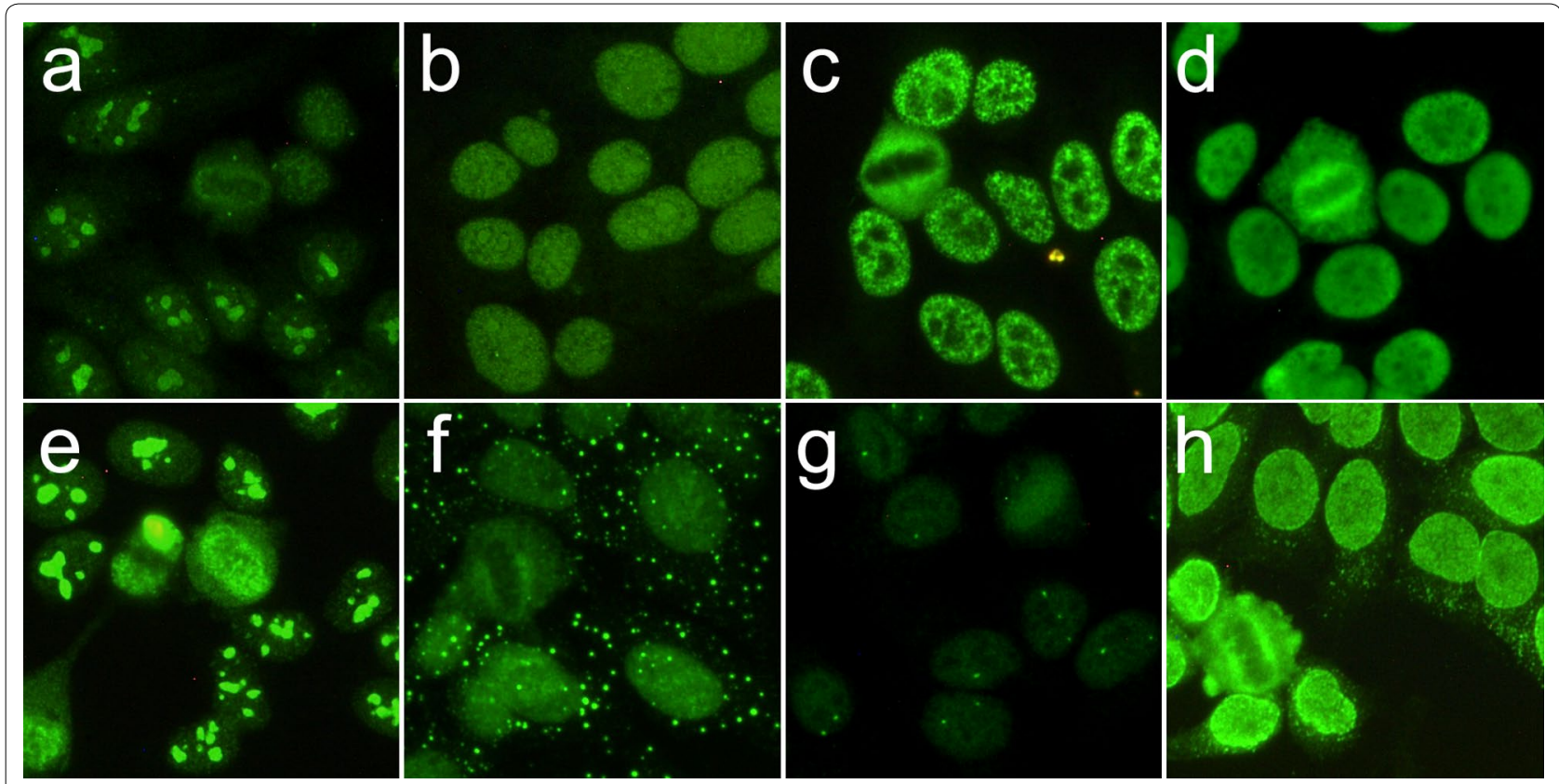

Fig. 3 Myositis-associated autoantibodies and some peculiar IIF pattern on HEp-2 ANA slides (EUROIMMUN, Lübeck, Germany). a anti-PM-Scl-100, b anti-PM-Scl-75, $\mathbf{c}$ anti-U1-snRNP, $\mathbf{d}$ anti-Ku, e anti-fibrillarin, $\mathbf{f}$ cytoplasmic discrete dots as seen in anti-Su/Ago2, $\mathbf{g}$ nuclear few nuclear dots as seen in anti-SMN, $\mathbf{h}$ punctate nuclear envelope as seen in anti-NUP 


\section{Anti-RNP}

The RNP/Sm complex comprises several proteins $(70 \mathrm{kD}$, $\left.\mathrm{A}, \mathrm{A}^{\prime}, \mathrm{B}, \mathrm{B}^{\prime}, \mathrm{B}^{\prime \prime}, \mathrm{C}, \mathrm{D}, \mathrm{E}, \mathrm{F}, \mathrm{G}\right)$ and five RNA (U1, U2, U4, $\mathrm{U} 5$ and U6). U1 RNA interacts with $70 \mathrm{kD}, \mathrm{A}$ and $\mathrm{C}$ to create the U1-snRNP [127]. High-titre anti-U1-snRNP and in particular when targeting the $70 \mathrm{kD}$ protein are considered specific markers of mixed connective tissue disease (MTCD), whereas low titres can be found in other CTDs [127].

Many home-made or commercial assays can detect anti-RNP autoantibodies, with differences among immunoassays depending on the immobilized antigen [127]. Usually, anti-U1-snRNP (more often the 70k subunit) and the anti-Sm (typically the D subunit) are the only autoantibodies tested in clinical practice. Large speckled and large coarse speckled are the most frequent HEp-2 IIF patterns observed (Fig. 3c).

Patients with myositis may exhibit anti-U1-snRNP positivity, especially those with a mild disease [128, 129]. They are usually steroid-responsive, even though ILD and/or neurological involvement may be part of the clinical presentation $[128,129]$. Whether the only presence of anti-U1-snRNP and myositis has to be considered an incomplete form of MTCD or a true myositis, is still a matter of debate $[128,129]$. In addition, anti-U2RNP [130], U5-RNP [131] and anti-U4/U6-RNP [132] have been described in patients with PM/SSc overlap syndrome.

\section{Anti-fibrillarin}

Fibrillarin, a highly conserved nucleolar $34 \mathrm{kDa}$ protein involved in the processing of ribosomal RNA, is part of the U3-small nucleolar (sno)-RNP complex together with other proteins and U3 RNA. Fibrillarin is the primary target of anti-U3-snoRNP autoantibodies [133]. IP is the gold standard for its detection showing good concordance with IB assays that use the recombinant protein [134].

HEp-2 IIF demonstrates a typical "clumpy" nucleolar pattern, with jagged staining of the nucleoli, coiled bodies and peri-chromosomal staining at the metaphase plates [135] (Fig. 3e).

Anti-fibrillarin antibodies are detected in a small percentage of SSc patients and rarely in SLE, primary Raynaud's phenomenon and myositis [136]. In detail, they identify a subset of SSc patients more often of African origin, with serious cutaneous and visceral involvement and a higher prevalence of myositis [137, 138].

\section{Anti-Ku}

The $\mathrm{Ku}$ protein, involved in the canonical non-homologous end-joining pathway of the DNA repair, is a heterodimer consisting of the two subunits, 70 and $80 \mathrm{kDa}$
[139]. Anti-Ku can be identified with numerous assays, such as ELISA, CIE or IB. IIF demonstrates a fine speckled nuclear pattern with a peculiar ring beam surrounding the metaphase on HEp-2 cells and a clumpy speckled pattern on primate's liver [140] (Fig. 3d).

Anti-Ku autoantibodies have been identified in $9-19 \%$ of the patients with PM/SSc overlap syndromes and SLE, being associated with arthralgia, Raynaud's phenomenon and ILD [141, 142]. Of note, whilst muscular involvement seems to be steroid-sensitive, ILD is more frequently progressive, severe and steroid-resistant [143].

\section{Anti-Ro}

Antibodies directed against the ribonucleoproteic complex SSA/Ro and SSB/La have been originally identified in $\mathrm{SjS}$ and SLE. Actually, antigen Ro is made by two separate complexes of 52 and $60 \mathrm{kDa}$ called Ro52/TRIM21 and SSA/Ro60, respectively. Antigen SSB/La has a molecular weight of $48 \mathrm{kDa}$ [144].

ANA may result falsely negative on traditional HEp-2 cells when isolate anti-Ro are present, because Ro52 is a cytoplasmic antigen and Ro60 may be lost during the preparation. For this reason, human SSA/Ro60-transfected HEp-2 cells (HEp-2000) are sometimes used [145, 146]. Otherwise, a characteristic pattern defined as "myriad discrete fine speckled" may be observed [147]. AntiSSB autoantibodies show a similar pattern [148].

Anti-Ro52 can be found in IIMs [149] and are frequently associated with other MSAs, in particular anti-synthetase [28], anti-MDA5 [61] and anti-SRP autoantibodies [12].

They are known to be a negative prognostic factor regarding systemic involvement such as ILD, whereas their role in the severity of muscular involvement has not been identified [13]. Anti-Ro52 autoantibodies are known to be associated with atrioventricular congenital heart block [150].

\section{Anti-cN-1A}

Cytosolic 5'nucleotidase $1 \mathrm{~A} \quad$ (cN-1A o NT5C1A) is a protein involved in the hydrolysis of adenosine monophosphate, controlling energy and metabolic cell balance [151]. Anti-cN-1A autoantibodies, first called anti-Mup44, were simultaneously described by Salajegheh et al. and Pluk et al. [152, 153] as targeting a $44 \mathrm{kDa}$ protein in patients with sIBM.

These autoantibodies were initially detected by immunoblotting from purified skeletal muscle extracts [153]. A novel standardized IgG ELISA is now available [154]. In addition to IgG, circulating IgA and IgM anti-cN-1A autoantibodies have been recognized [155]. IIF ANA pattern is still undefined. 
Anti-cN-1A autoantibodies are demonstrated in onethird of the patients with sIBM and in less than $5 \%$ with other IIMs or neuromuscular diseases [151]. A recent study demonstrated that positive anti-cN-1A sIBM patients are included in a more severe sIBM subtype and represent a homogeneous group as exhibiting higher mortality risk, less proximal upper limb weakness (not typical of sIBMs) and a cytochrome oxidase deficiency in muscular fibers, when compared to negative patients [156].

It is not known whether they have to be considered as MSAs or MAAs as also demonstrated in other autoimmune diseases, such as SjS (30\%) and SLE (20\%) [157]. Furthermore, they have been recently demonstrated in a cohort of severe juvenile myositis with lung involvement, juvenile idiopathic arthritis, but also in $12 \%$ of healthy children [158].

Despite low sensitivity, anti-cN-1A autoantibodies are high specific and highly predictive of sIBM [159] thus being of particular importance when bioptic specimens are not diagnostic.

\section{Miscellaneous autoantibodies in IIM}

Several other autoantibodies have been identified as associated with IIMs, but little is known about their clinical relevance. In fact, they are not routinely determined because easy-to-perform routine specific immunoassays still lack and they are rarely found.

\section{Anti-RuvBL1/2}

RuvBL1 (49kD) and RuvBL2 (48kD) constitute a nuclear complex involved into DNA repair and transcription. Two distinct bands of approximately $50 \mathrm{kDa}$ are found in IP [160]. By means of ELISA and/or IB techniques, antiRuvBL1/2 have been found in several CTDs, but those involved in SSc and myositis recognize different conformational epitopes identified by IP exclusively [160]. On HEp-2 cells, a fine speckled pattern is associated with these antibodies, with increased fluorescence in prophase and decreased in metaphase. Additionally, a fine speckled pattern can be found in the cytoplasm of about $40 \%$ positive sera [160]. Anti-RuvBL1/2 antibodies are highly specific for SSc, are associated with PM/SSc overlaps with diffuse cutaneous sclerosis and more frequently found in older patients of male sex [160-162] or, less frequently, in necrotizing polymyositis with morphea [162].

\section{Anti-Su/Ago2}

Anti-Su/Argonaute-2 (anti-Su/Ago2) autoantibodies have been originally identified in SLE patients by means of immunodiffusion technique in the late '80ies [163]. Although their high prevalence in CTDs, few studies are available.
By IP, two distinct 100 and $102 \mathrm{kDa}$ adjacent bands can be seen in addition to a further $200 \mathrm{kDa}$ band [164]. Argonaute- 2 protein constitutes the $100 \mathrm{kDa}$ band and plays a key role in miRNA and interference RNA maturation and metabolism [163]. Argonaute- 2 colocalized with $\mathrm{GW}$ bodies, a cytoplasmic organelle associated with RNA metabolism [164]. Its location and function is responsible for the particular cytoplasmic pattern of these autoantibodies also known as "GW-bodies-like" or "cytoplasmic discrete dots" (Fig. 3f) [164].

Anti-Su/Ago2 autoantibodies are frequently associated with other MSA or MAA antibodies, in particular ARS, anti-TIF-1 $\gamma$ and anti-MDA5 [165]; anti-Ro52 antibodies are found in almost one half of the patients [166]. It has been reported that anti-Su/Ago2 antibodies can be demonstrated in about $7.5 \%$ of the patients of Japanese origin. Apparently, there is no statistical difference between anti$\mathrm{Su} /$ Ago 2 positive and negative patients; however, a correlation seems to exist with ILD and absence of cancers [165].

\section{Anti-SMN}

The Survival of Motor Neuron (SMN) is a multi-ribonucleoproteic complex able to interact with the RNPcomplex related D-E-F-G proteins. The SMN complex is involved into the assembly of snRNPs and co-localizes with Cajal bodies. These autoantibodies have been first described in a small number of PM patients negative for anti-U1-snRNP and/or anti-Sm but positive for RNP D-E-F-G bands by IP. This observation was indeed responsible for the identification of other SMN-complex components, namely Gemin $2(33 \mathrm{kDa})$, Gemin 3 $(130 \mathrm{kDa})$, Gemin $4(120 \mathrm{kDa})$ and SMN itself $(38 \mathrm{kDa})$ [167].

Anti-SMN antibodies typically exhibit a few nuclear dots pattern on HEp-2 cells with well distinguished 2-7 nuclear dots, similarly to anti-p80-coilin, anti-NXP2 and anti-PML pattern, seldom associated to cytoplasmic or nuclear speckled patterns (Fig. 3g).

It is not clear whether positive patients exhibit distinct clinical features. Anyhow, in the original small group of positive patients [167] and a small Italian cohort [20], a $\mathrm{PM} / \mathrm{SSc}$ overlap syndrome was present. It is of note that SMN-complex genetic mutations are frequently found in neuromuscular degenerative diseases such as spinalmuscle atrophy. That is why anti-SMN autoantibodies are of relevance in basic research [168].

\section{Anti-NPC}

Nuclear pore complex (NPC) regulates protein and RNA trafficking to the nucleus. It is constituted by a complex of several proteins including Nup358/RanBP2, Nup90, Nup62 and gp210 [169]. Anti-NPC autoantibodies, 
and, in particular, anti gp210 are typically associated to Primary Biliary Cholangitis (PBC) and Autoimmune Hepatitis (AIH) [170]. In a cohort study from Canada, anti-NPC antibodies were found in a PM/SSc overlap syndrome and called anti-NUP Syndrome, which was found to be associated with HLA-DQ1*0501. In this case, a typical nuclear speckled laminar pattern on HEp-2 cells was observed [171] (Fig. 3h).

\section{AMA-M2}

Among the ten different anti-mitochondrial antibodies (AMA), called M1-M10, anti-M2 antibodies (AMAM2) are the hallmark of PBC [172]. However, they can be also found in $7-12 \%$ of IIM patients without PBC [173]. AMA antibodies are readily detectable on HEp-2 cells as they display a pathognomonic cytoplasmic reticular pattern, and in triple tissue slides (Fig. 2d-f). In a Japanese study, the presence of AMA-M2 in the course of IIM was associated with muscle atrophy, granuloma formation [173] and heart involvement with high risk of supraventricular arrhythmias [174]. A distinct inflammatory phenotype associated with chronic skeletal muscle disease and severe cardiac involvement was also found in a North American cohort [175]. These associations have not been confirmed in an European series [176].

\section{Other antibodies}

Several cytoplasmic autoantibodies are described in IIM patients such as anti-KJ towards a $30 / 43 \mathrm{kDa}$ translocation factor [177], anti-Fer directed against the elongation factor 1 and anti-Wa recognizing a $48 \mathrm{kDa}$ cytoplasmic protein with still unknown function [132]. All these antibodies are typically found in anti-synthetase-like syndromes. Anti-Mas antibodies are directed against a selenocysteine-containing tRNA complex lacking any tRNA-synthetase activity but involved in protein translocation. The band of precipitation is found at $48 \mathrm{kDa}$ [178]. These antibodies have been described in AIH and in a single patient with non-immune mediated rhabdomyolysis [178].

DNA-repairing complexes, especially mismatchrepair complexes such as PMS1, PMS2 and MLH1, are frequently recognized as target antigens in IIMs [179]. Initially defined as MSAs, they do indeed frequently associate with other MSAs, in particular anti-Mi-2, but they can also be found in other non-muscular diseases, such as SLE. They generally mark mild disease [180].

Anti-cortactin antibodies have been initially found in IIM patients characterized by the simultaneous presence of anti-MDA 5 or anti-HMGCR antibodies by ELISA [181]. As blot confirming assay identified an unexpected $68 \mathrm{kDa}$ band, it was then found that MDA5 and HMGCR extracts used in the ELISA tests were contaminated by cortactin [181]. Anti-cortactin antibodies were originally found in myasthenia gravis [182] and later in IIM patients (about 20\%) and other systemic connective tissue diseases [181].

Anti-Four-and-a-Half LIM domain 1 (FHL1) antibodies were identified in about $25 \%$ of IIM patients. These antibodies associated with a severe prognosis, muscle atrophy, vasculitis, dysphagia and advanced muscular damage. Curiously, FHL1 mutations cause hereditary X-linked congenital myopathies [183].

\section{Conclusions}

Although autoantibodies are considered to be epiphenomenon in autoimmunity, their presence frequently plays a pivotal role for the diagnosis of these diseases. Indeed, several of them exhibit a pathogenethic role in IIMs. Despite this, there is still a gap between bench and bedside because the intense basic research efforts have not been translated in clinical practice, as already futuristically underlined more than 20 years ago [96, 184]. As a fact, only anti-Jo-1 have been included into the 2017 Classification Criteria for Adult and Juvenile IIMs [3].

Remarkably, in the context of heterogeneously grouped diseases such as myositis, they should be even more appreciated as able to clinically stratify patients in terms of diagnostic work-up, histological patterns, peculiar organ involvement, severity, and, therefore, treatment intensity and prognosis. This process could be accomplished by a laboratory auto-immunologist [185] welltrained in recognition of IIF ANA nuclear and, also, cytoplasmic patterns, in strict collaboration with the clinical doctor, as a decision-maker for running indepth analysis towards the identification of the culprit autoantibody.

In addition, multicentric studies with a multidisciplinary approach may help bridging the divide of the selection bias depending on the setting where patients are initially screened (i.e. pneumologic vs. dermatologic vs. immuno-rheumatologic vs. neurologic outpatient clinics).

\section{Abbreviations}

SLE: systemic lupus erythematosus; CTD: connective tissue disease; SjS: Sjögren syndrome; SSc: systemic sclerosis; IIM: idiopathic inflammatory myopathies; PM: polymyositis; DM: dermatomyositis; MSA: myositis-specific autoantibodies; MAA: myositis-associated autoantibodies; ARS: anti-synthetase autoantibodies; IPAF: interstitial pneumonia with autoimmune features; IIF: indirect immuno-fluorescence; CIE: counter-immuno-electrophoresis; ID: immuno-diffusion; ELISA: enzyme-linked immunosorbent assay; FEIA: fluorescent enzyme-linked assay; CLIA: chemiluminescent immuno-assay; IP: immuno-precipitation; ALBIA: addressable laser beads immunoassay; ANA: anti-nuclear autoantibodies; IB: immunoblot; LIA: line blot assays; tRNA: transfer RNA; DID: double immune-diffusion; ILD: interstitial lung disease; ASSD: antisynthetase syndrome; PM/DM: polymyositis/dermatomyositis; NuRD: nucleosome remodelling deacetylase; sIBM: sporadic inclusion body myositis; CK: creatine kinase; SUMOs: small ubiquitin-like modifiers; SAE: 
SUMO-activating enzyme; MDA5: Melanoma Differentiation-Associated gene 5; RIG-I: retinoic acid-inducible gene I; RLR: RIG-Ilike receptors family; RP-ILD: rapidly progressive interstitial lung disease; CADM: clinically amyopathic dermatomyositis; TIF1: transcription intermediary factors-1; TRIM: tripartite motif-containing proteins; NXP-2: nuclear matrix protein 2; PML: pro-myelocitic leukaemia bodies; SRP: signal recognition particle; IMNM: immune-mediated necrotizing myositis; HMGCR: 3-hydroxy-3-methylglutaryl-coenzime A reductase; HALIP: anti-HMGCR antibody associated liver immunofluorescence pattern; MTCD: mixed connective tissue disease; sno: small nucleolar; cN-1A: cytosolic 5'nucleotidase; SMN: survival of motor neuron; NPC: nuclear pore complex; PBC: primary biliary cholangitis; AlH: autoimmune hepatitis; FHL1: anti-four-and-a-half LIM domain 1; AMA: anti-mitochondrial antibodies.

\section{Authors' contributions}

BP and GV drafted the manuscript. All authors read and approved the final manuscript.

\section{Acknowledgements}

We thank the team of Immunoallergology Laboratory, AOU-Careggi, Florence for the great deal of teamwork and constant readiness to our requests.

\section{Competing interests}

The authors declare that they have no competing interests.

\section{Availability of data and materials}

Not applicable.

\section{Consent for publication}

Not applicable.

\section{Ethics approval and consent to participate}

Not applicable.

\section{Funding}

This research received no specific grant from any funding agency in the public, commercial, or not-for-profit sectors.

\section{Publisher's Note}

Springer Nature remains neutral with regard to jurisdictional claims in published maps and institutional affiliations.

Received: 31 January 2018 Accepted: 20 February 2018

Published online: 07 March 2018

\section{References}

1. Petri M, Orbai A-M, Alarcón GS, Gordon C, Merrill JT, Fortin PR, et al. Derivation and validation of the Systemic Lupus International Collaborating Clinics classification criteria for systemic lupus erythematosus. Arthritis Rheum. 2012;64:2677-86.

2. Shiboski CH, Shiboski SC, Seror R, Criswell LA, Labetoulle M, Lietman TM, et al. 2016 American College of Rheumatology/European League Against Rheumatism classification criteria for primary Sjögren's syndrome. Ann Rheum Dis. 2017;76:9-16.

3. Lundberg IE, Tjärnlund A, Bottai M, Werth VP, Pilkington C, de Visser M, et al. 2017 European League Against Rheumatism/American College of Rheumatology classification criteria for adult and juvenile idiopathic inflammatory myopathies and their major subgroups. Ann Rheum Dis. 2017;76:1955-64.

4. Milone M. Diagnosis and Management of Immune-Mediated Myopathies. Mayo Clin Proc. 2017;92:826-37.

5. Targoff IN. Autoantibodies in polymyositis. Rheum Dis Clin North Am. 1992;18:455-82.

6. Targoff IN. Idiopathic inflammatory myopathy: autoantibody update. Curr Rheumatol Rep. 2002:4:434-41.

7. Satoh M, Tanaka S, Ceribelli A, Calise SJ, Chan EKL. A comprehensive overview on myositis-specific antibodies: new and old biomarkers in idiopathic inflammatory myopathy. Clin Rev Allergy Immunol. 2015;52:1-9.

8. Nakashima R, Imura Y, Hosono Y, Seto M, Murakami A, Watanabe K, et al. The multicenter study of a new assay for simultaneous detection of multiple anti-aminoacyl-tRNA synthetases in myositis and interstitial pneumonia. PLOS ONE. 2014;9:e85062.

9. Colafrancesco S, Priori R, Valesini G. Inflammatory myopathies and overlap syndromes: update on histological and serological profile. Best Pract Res Clin Rheumatol. 2015;29:810-25.

10. Gunawardena H, Betteridge ZE, McHugh NJ. Myositis-specific autoantibodies: their clinical and pathogenic significance in disease expression. Rheumatology (Oxford). 2009;48:607-12.

11. Chinoy H, Fertig N, Oddis CV, Ollier WER, Cooper RG. The diagnostic utility of myositis autoantibody testing for predicting the risk of cancerassociated myositis. Ann Rheum Dis. 2007;66:1345-9.

12. Frank MB, McCubbin V, Trieu E, Wu Y, Isenberg DA, Targoff IN. The association of anti-Ro52 autoantibodies with myositis and scleroderma autoantibodies. J Autoimmun. 1999;12:137-42.

13. Ferreira JP, Almeida I, Marinho A, Cerveira C, Vasconcelos C. Anti-ro52 antibodies and interstitial lung disease in connective tissue diseases excluding scleroderma. ISRN Rheumatol. 2012;2012:415272.

14. van Dooren SHJ, van Venrooij WJ, Pruijn GJM. Myositis-specific autoantibodies: detection and clinical associations. Autoimmun Highlights. 2011;2:5-20.

15. Chan EKL, Damoiseaux J, Carballo OG, Conrad K, de Melo Cruvinel W, Francescantonio PLC, et al. Report of the first international consensus on standardized nomenclature of antinuclear antibody HEp-2 cell patterns 2014-2015. Front Immunol. 2015;6:412.

16. García-DeLaTorre I. Clinical usefulness of autoantibodies in idiopathic inflammatory myositis. Front Immunol. 2015;6:331.

17. Damoiseaux J, von Mühlen CA, Garcia-De La Torre I, Carballo OG, de Melo Cruvinel W, Francescantonio PLC, et al. International consensus on ANA patterns (ICAP): the bumpy road towards a consensus on reporting ANA results. Autoimmun Highlights. 2016;7:1-8.

18. Ghirardello A, Bendo R, Rampudda ME, Bassi N, Zampieri S, Doria A. Commercial blot assays in the diagnosis of systemic rheumatic diseases. Autoimmun Rev. 2009;8:645-9.

19. Rönnelid J, Barbasso Helmers S, Storfors H, Grip K, Rönnblom L, FranckLarsson K, et al. Use of a commercial line blot assay as a screening test for autoantibodies in inflammatory myopathies. Autoimmun Rev. 2009;9:58-61.

20. Cavazzana I, Fredi M, Ceribelli A, Mordenti C, Ferrari F, Carabellese N, et al. Testing for myositis specific autoantibodies: comparison between line blot and immunoprecipitation assays in 57 myositis sera. J Immunol Methods. 2016:433:1-5.

21. Ceribelli A, Satoh M, Chan EK. A new immunoprecipitation-real time quantitative PCR assay for anti-Th/To and anti-U3RNP antibody detection in systemic sclerosis. Arthritis Res Ther. 2012;14:R128.

22. Mahler M, Miller FW, Fritzler MJ. Idiopathic inflammatory myopathies and the anti-synthetase syndrome: a comprehensive review. Autoimmun Rev. 2014;13:367-71.

23. Nishikai M, Reichlin M. Heterogeneity of precipitating antibodies in polymyositis and dermatomyositis. Characterization of the Jo-1 antibody system. Arthritis Rheum. 1980;23:881-8.

24. Agmon-Levin N, Damoiseaux J, Kallenberg C, Sack U, Witte T, Herold M, et al. International recommendations for the assessment of autoantibodies to cellular antigens referred to as anti-nuclear antibodies. Ann Rheum Dis. 2014;73:17-23.

25. Infantino M, Palterer B, Biagiotti R, et al. Reflex testing of speckled cytoplasmic patterns observed in routine ANA HEp-2 indirect immunofluorescence with a multiplex anti-synthetase dot-blot assay: a multicentric pilot study. Immunol Res. 2018;66(1):74-8.

26. Abe T, Tsunoda S, Nishioka A, Azuma K, Tsuboi K, Ogita C, et al. Reliability and clinical utility of enzyme-linked immunosorbent assay for detection of anti-aminoacyl-tRNA synthetase antibody. Nihon Rinsho Meneki Gakkai Kaishi. 2016:39:140-4.

27. Yoshida S, Akizuki M, Mimori T, Yamagata H, Inada S, Homma M. The precipitating antibody to an acidic nuclear protein antigen, the Jo-1, in connective tissue diseases. A marker for a subset of polymyositis with interstitial pulmonary fibrosis. Arthritis Rheum. 1983;26:604-11. 
28. Yamasaki Y, Satoh M, Mizushima M, Okazaki T, Nagafuchi H, Ooka S, et al. Clinical subsets associated with different anti-aminoacyl transfer RNA synthetase antibodies and their association with coexisting anti-Ro52. Mod Rheumatol. 2016;26:403-9.

29. Yamasaki Y, Yamada H, Nozaki T, Akaogi J, Nichols C, Lyons R, et al. Unusually high frequency of autoantibodies to PL-7 associated with milder muscle disease in Japanese patients with polymyositis/dermatomyositis. Arthritis Rheum. 2006;54:2004-9.

30. Marie I, Josse S, Decaux O, Diot E, Landron C, Roblot P, et al. Clinical manifestations and outcome of anti-PL7 positive patients with antisynthetase syndrome. Eur J Intern Med. 2013;24:474-9.

31. Targoff IN, Arnett FC. Clinical manifestations in patients with antibody to PL-12 antigen (alanyl-tRNA synthetase). Am J Med. 1990;88:241-51.

32. Hirakata M, Suwa A, Nagai S, Kron MA, Trieu EP, Mimori T, et al. Anti-KS: identification of autoantibodies to asparaginyl-transfer RNA synthetase associated with interstitial lung disease. J Immunol. 1999;162:2315-20.

33. Scirè CA, Gonzalez-Gay MA, Selva-O'Callaghan A, Cavagna L, SelvaO'Callaghan A, Cavagna L. Clinical spectrum time course of interstitial pneumonia with autoimmune features in patients positive for antisynthetase antibodies. Respir Med. 2017;132:265-6.

34. Cavagna L, Nuño L, Scirè CA, Govoni M, Longo FJL, Franceschini F, et al. Clinical spectrum time course in anti Jo-1 positive antisynthetase syndrome: results from an international retrospective multicenter study. Medicine (Baltimore). 2015;94:e1144.

35. Casal-Dominguez M, Pinal-Fernandez I, Mego M, Accarino A, Jubany L, Azpiroz $F$, et al. High-resolution manometry in patients with idiopathic inflammatory myopathy: Elevated prevalence of esophageal involvement and differences according to autoantibody status and clinical subset. Muscle Nerve. 2016;45(suppl_4):iv18-21.

36. Pestronk A. Acquired immune and inflammatory myopathies. Curr Opin Rheumatol. 2011;23:595-604.

37. Mescam-Mancini L, Allenbach Y, Hervier B, Devilliers H, Mariampillay $K$, Dubourg $\mathrm{O}$, et al. Anti-Jo-1 antibody-positive patients show a characteristic necrotizing perifascicular myositis. Brain. 2015;138(Pt 9):2485-92.

38. Aouizerate J, De Antonio M, Bassez G, Gherardi RK, Berenbaum F, Guillevin L, et al. Myofiber HLA-DR expression is a distinctive biomarker for antisynthetase-associated myopathy. Acta Neuropathol Commun. 2014;2:154.

39. Targoff IN, Reichlin M. The association between Mi-2 antibodies and dermatomyositis. Arthritis Rheum. 1985;28:796-803.

40. Ghirardello A, Zampieri S, laccarino L, Tarricone E, Bendo R, Gambari PF, et al. Anti-Mi-2 antibodies. Autoimmunity. 2005:38:79-83.

41. Nilasena DS, Trieu EP, Targoff IN. Analysis of the Mi-2 autoantigen of dermatomyositis. Arthritis Rheum. 1995:38:123-8.

42. Zhang Y, LeRoy G, Seelig HP, Lane WS, Reinberg D. The dermatomyositis-specific autoantigen Mi2 is a component of a complex containing histone deacetylase and nucleosome remodeling activities. Cell. 1998;95:279-89.

43. Petri MH, Satoh M, Martin-Marquez BT, Vargas-Ramírez R, Jara LJ, Saavedra MA, et al. Implications in the difference of anti-Mi-2 and -p155/140 autoantibody prevalence in two dermatomyositis cohorts from Mexico City and Guadalajara. Arthritis Res Ther. 2013;15:R48.

44. Love LA, Weinberg CR, McConnaughey DR, Oddis CV, Medsger TA, Reveille JD, et al. Ultraviolet radiation intensity predicts the relative distribution of dermatomyositis and anti-Mi-2 autoantibodies in women. Arthritis Rheum. 2009;60:2499-504.

45. Prieto $\mathrm{S}$, Grau JM. The geoepidemiology of autoimmune muscle disease. Autoimmun Rev. 2010;9:A330-4.

46. Tarricone E, Ghirardello A, Rampudda M, Bassi N, Punzi L, Doria A. AntiSAE antibodies in autoimmune myositis: identification by unlabelled protein immunoprecipitation in an Italian patient cohort. J Immunol Methods. 2012;384:128-34

47. Betteridge Z, Gunawardena H, North J, Slinn J, McHugh N. Identification of a novel autoantibody directed against small ubiquitin-like modifier activating enzyme in dermatomyositis. Arthritis Rheum. 2007;56:3132-7.

48. Ge Y, Lu X, Shu X, Peng Q, Wang G. Clinical characteristics of anti-SAE antibodies in Chinese patients with dermatomyositis in comparison with different patient cohorts. Sci Rep. 2017;7:188.
49. Muro Y, Sugiura K, Akiyama M. Low prevalence of anti-small ubiquitinlike modifier activating enzyme antibodies in dermatomyositis patients. Autoimmunity. 2013;46:279-84.

50. Fujimoto M, Matsushita T, Hamaguchi Y, Kaji K, Asano Y, Ogawa F, et al. Autoantibodies to small ubiquitin-like modifier activating enzymes in Japanese patients with dermatomyositis: comparison with a UK Caucasian cohort. Ann Rheum Dis. 2013;72:151-3.

51. Betteridge ZE, Gunawardena H, Chinoy H, North J, Ollier WER, Cooper $\mathrm{RG}$, et al. Clinical and human leucocyte antigen class II haplotype associations of autoantibodies to small ubiquitin-like modifier enzyme, a dermatomyositis-specific autoantigen target, in UK Caucasian adultonset myositis. Ann Rheum Dis. 2009;68:1621-5.

52. Muro Y, Sugiura K, Nara M, Sakamoto I, Suzuki N, Akiyama M. High incidence of cancer in anti-small ubiquitin-like modifier activating enzyme antibody-positive dermatomyositis. Rheumatology (Oxford). 2015;54:1745-7.

53. Nakashima R, Imura Y, Kobayashi S, Yukawa N, Yoshifuji H, Nojima T, et al. The RIG-I-like receptor IFIH1/MDA5 is a dermatomyositis-specific autoantigen identified by the anti-CADM-140 antibody. Rheumatology (Oxford). 2010;49:433-40.

54. Sato S, Hirakata M, Kuwana M, Suwa A, Inada S, Mimori T, et al. Autoantibodies to a 140-kd polypeptide, CADM-140, in Japanese patients with clinically amyopathic dermatomyositis. Arthritis Rheum. 2005;52:1571-6.

55. Sato S, Hoshino K, Satoh T, Fujita T, Kawakami Y, Fujita T, et al. RNA helicase encoded by melanoma differentiation-associated gene 5 is a major autoantigen in patients with clinically amyopathic dermatomyositis: association with rapidly progressive interstitial lung disease. Arthritis Rheum. 2009:60:2193-200.

56. Parronchi P, Radice A, Palterer B, Liotta F, Scaletti C. MDA5-positive dermatomyositis: an uncommon entity in Europe with variable clinical presentations. Clin Mol Allergy. 2015;13:22.

57. Zhang L, Wu G, Gao D, Liu G, Pan L, Ni L, et al. Factors Associated with interstitial lung disease in patients with polymyositis and dermatomyositis: a systematic review and meta-analysis. PLOS ONE. 2016;11:e0155381.

58. Chen Z, Hu W, Wang Y, Guo Z, Sun L, Kuwana M. Distinct profiles of myositis-specific autoantibodies in Chinese and Japanese patients with polymyositis/dermatomyositis. Clin Rheumatol. 2015;34:1627-31.

59. Ceribelli A, Fredi M, Taraborelli M, Cavazzana I, Tincani A, Selmi C, et al. Prevalence and clinical significance of anti-MDA5 antibodies in European patients with polymyositis/dermatomyositis. Clin Exp Rheumatol. 2014;32:891-7.

60. Labrador-Horrillo M, Martinez MA, Selva-O'Callaghan A, Trallero-Araguas E, Balada E, Vilardell-Tarres M, et al. Anti-MDA5 antibodies in a large Mediterranean population of adults with dermatomyositis. J Immunol Res. 2014;2014:290797.

61. Hall JC, Casciola-Rosen L, Samedy L-A, Werner J, Owoyemi K, Danoff SK, et al. Anti-melanoma differentiation-associated protein 5-associated dermatomyositis: expanding the clinical spectrum. Arthritis Care Res (Hoboken). 2013;65:1307-15.

62. Muro Y, Sugiura K, Hoshino K, Akiyama M, Tamakoshi K. Epidemiologic study of clinically amyopathic dermatomyositis and anti-melanoma differentiation-associated gene 5 antibodies in central Japan. Arthritis Res Ther. 2011;13:R214.

63. Chen Z, Wang Y, Kuwana M, Xu X, Hu W, Feng X, et al. HLA-DRB1 alleles as genetic risk factors for the development of anti-MDA5 antibodies in patients with dermatomyositis. J Rheumatol. 2017;44:1389-93.

64. Ward I, Hiles P, Arroyo R, Downs W, Bell D. Digital pulp ulcerations and inverse gottron papules in melanoma differentiation-associated gene 5-related dermatomyositis. J Clin Rheumatol. 2016;22:274-5.

65. Cao H, Xia Q, Pan M, Zhao X, Li X, Shi R, et al. Gottron papules and gottron sign with ulceration: a distinctive cutaneous feature in a subset of patients with classic dermatomyositis and clinically amyopathic dermatomyositis. J Rheumatol. 2016;43:1735-42.

66. Fiorentino D, Chung L, Zwerner J, Rosen A, Casciola-Rosen L. The mucocutaneous and systemic phenotype of dermatomyositis patients with antibodies to MDA5 (CADM-140): a retrospective study. J Am Acad Dermatol. 2011;65:25-34.

67. Tansley SL, Simou S, Shaddick G, Betteridge ZE, Almeida B, Gunawardena $\mathrm{H}$, et al. Autoantibodies in juvenile-onset myositis: their 
diagnostic value and associated clinical phenotype in a large UK cohort. J Autoimmun. 2017;84:55-64.

68. Gono T, Kawaguchi Y, Hara M, Masuda I, Katsumata Y, Shinozaki M, et al. Increased ferritin predicts development and severity of acute interstitial lung disease as a complication of dermatomyositis. Rheumatology (Oxford). 2010;49:1354-60.

69. Muro Y, Sugiura K, Akiyama M. Limitations of a single-point evaluation of anti-MDA5 antibody, ferritin, and IL-18 in predicting the prognosis of interstitial lung disease with anti-MDA5 antibody-positive dermatomyositis. Clin Rheumatol. 2013;32:395-8.

70. Fujimoto M, Hamaguchi Y, Kaji K, Matsushita T, Ichimura Y, Kodera M et al. Myositis-specific anti-155/140 autoantibodies target transcription intermediary factor 1 family proteins. Arthritis Rheum. 2012;64:513-22.

71. Targoff IN, Mamyrova G, Trieu EP, Perurena O, Koneru B, O'Hanlon TP, et al. A novel autoantibody to a $155-\mathrm{kd}$ protein is associated with dermatomyositis. Arthritis Rheum. 2006;54:3682-9.

72. Kaji K, Fujimoto M, Hasegawa M, Kondo M, Saito Y, Komura K, et al. Identification of a novel autoantibody reactive with 155 and $140 \mathrm{kDa}$ nuclear proteins in patients with dermatomyositis: an association with malignancy. Rheumatology (Oxford). 2007;46:25-8.

73. Satoh M, Chan JYF, Ross SJ, Li Y, Yamasaki Y, Yamada H, et al. Autoantibodies to transcription intermediary factor TIF1 $\beta$ associated with dermatomyositis. Arthritis Res Ther. 2012;14:R79.

74. Labrador-Horrillo M, Martínez MA, Selva-O'Callaghan A, Trallero-Araguás E, Balada E, Vilardell-Tarrés M, et al. Anti-TIF1Y antibodies (anti-p155) in adult patients with dermatomyositis: comparison of different diagnostic assays. Ann Rheum Dis. 2012;71:993-6.

75. Muro Y, Ishikawa A, Sugiura K, Akiyama M. Clinical features of anti-TIF1-a antibody-positive dermatomyositis patients are closely associated with coexistent dermatomyositis-specific autoantibodies and anti-TIF1- $\gamma$ or anti-Mi-2 autoantibodies. Rheumatology (Oxford). 2012;51:1508-13.

76. Kasuya A, Hamaguchi Y, Fujimoto M, Tokura Y. TIF1Y-overexpressing, highly progressive endometrial carcinoma in a patient with dermatomyositis positive for malignancy-associated anti-p155/140 autoantibody. Acta Derm Venereol. 2013;93:715-6.

77. Mohassel P, Rosen P, Casciola-Rosen L, Pak K, Mammen AL. Expression of the dermatomyositis autoantigen transcription intermediary factor $1 Y$ in regenerating muscle. Arthritis Rheumatol. 2015;67:266-72.

78. Trallero-Araguás E, Rodrigo-Pendás JÁ, Selva-O'Callaghan A, MartínezGõmez X, Bosch X, Labrador-Horrillo M, et al. Usefulness of anti-p155 autoantibody for diagnosing cancer-associated dermatomyositis: a systematic review and meta-analysis. Arthritis Rheum. 2012;64:523-32.

79. Palterer B, Vitiello G, Cammelli D. First report of anti-TIF1Y dermatomyositis in a patient with myelodysplastic syndrome. Reumatismo. 2017:69:75-7.

80. Fiorentino DF, Kuo K, Chung L, Zaba L, Li S, Casciola-Rosen L. Distinctive cutaneous and systemic features associated with antitranscriptional intermediary factor-1 $\gamma$ antibodies in adults with dermatomyositis. J Am Acad Dermatol. 2015;72:449-55.

81. Bernet LL, Lewis MA, Rieger KE, Casciola-Rosen L, Fiorentino DF. Ovoid palatal patch in dermatomyositis: a novel finding associated with antiTIF1Y (p155) antibodies. JAMA Dermatol. 2016;152:1049-51.

82. Kimura Y, Sakai F, Nakano O, Kisaki O, Sugimoto H, Sawamura T, et al. The newly identified human nuclear protein NXP-2 possesses three distinct domains, the nuclear matrix-binding, RNA-binding, and coiled-coil domains. J Biol Chem. 2002;277:20611-7.

83. Targoff IN, Trieu EP, Levy-Neto M. Sera with autoantibodies to the MJ antigen react with NXP2. Arthritis Rheum. 2007;56:S787

84. Fredi M, Bartoli F, Cavazzana I, Ceribelli A, Carabellese N, Tincani A, et al. Calcinosis in poly-dermatomyositis: clinical and laboratory predictors and treatment options. Clin Exp Rheumatol. 2017;35:303-8.

85. Mimura Y, Takahashi K, Kawata K, Akazawa T, Inoue N. Two-step colocalization of MORC3 with PML nuclear bodies. J Cell Sci. 2010;123(Pt 12):2014-24.

86. Espada G, Maldonado Cocco JA, Fertig N, Oddis CV. Clinical and serologic characterization of an Argentine pediatric myositis cohort: identification of a novel autoantibody (anti-MJ) to a 142-kDa protein. J Rheumatol. 2009;36:2547-51.

87. Ichimura Y, Matsushita T, Hamaguchi Y, Kaji K, Hasegawa M, Tanino $Y$, et al. Anti-NXP2 autoantibodies in adult patients with idiopathic inflammatory myopathies: possible association with malignancy. Ann Rheum Dis. 2012;71:710-3.

88. Fiorentino DF, Chung LS, Christopher-Stine L, Zaba L, Li S, Mammen $\mathrm{AL}$, et al. Most patients with cancer-associated dermatomyositis have antibodies to nuclear matrix protein NXP-2 or transcription intermediary factor $1 \gamma$. Arthritis Rheum. 2013;65:2954-62.

89. Ceribelli A, Fredi M, Taraborelli M, Cavazzana I, Franceschini F, Quinzanin M, et al. Anti-MJ/NXP-2 autoantibody specificity in a cohort of adult Italian patients with polymyositis/dermatomyositis. Arthritis Res Ther. 2012;14:R97.

90. Tansley SL, Betteridge ZE, Shaddick G, Gunawardena H, Arnold K, Wedderburn $L R$, et al. Calcinosis in juvenile dermatomyositis is influenced by both anti-NXP2 autoantibody status and age at disease onset. Rheumatology (Oxford). 2014;53:2204-8.

91. Reeves WH, Nigam SK, Blobel G. Human autoantibodies reactive with the signal-recognition particle. Proc Natl Acad Sci USA. 1986;83:9507-11.

92. Picard C, Vincent T, Lega J-CC, Hue S, Fortenfant F, Lakomy D, et al. Heterogeneous clinical spectrum of anti-SRP myositis and importance of the methods of detection of anti-SRP autoantibodies: a multicentric study. Immunol Res. 2016;64:677-86.

93. Suzuki S, Nishikawa A, Kuwana M, Nishimura H, Watanabe Y, Nakahara $J$, et al. Inflammatory myopathy with anti-signal recognition particle antibodies: case series of 100 patients. Orphanet J Rare Dis. 2015;10:61.

94. Allenbach Y, Arouche-Delaperche L, Preusse C, et al. Necrosis in anti-SRP + and anti-HMGCR + myopathies: role of autoantibodies and complement. Neurology. 2018;90(6):e507-17.

95. Ikeda K, Mori-Yoshimura M, Yamamoto T, Sonoo M, Suzuki S, Kondo Y, et al. Chronic myopathy associated with anti-signal recognition particle antibodies can be misdiagnosed as facioscapulohumeral muscular dystrophy. J Clin Neuromuscul Dis. 2016;17:197-206.

96. Love LA, Leff RL, Fraser DD, Targoff IN, Dalakas M, Plotz PH, et al. A new approach to the classification of idiopathic inflammatory myopathy: myositis-specific autoantibodies define useful homogeneous patient groups. Medicine (Baltimore). 1991;70:360-74.

97. Aggarwal R, Oddis CV, Goudeau D, Fertig N, Metes I, Stephens C, et al. Anti-signal recognition particle autoantibody ELISA validation and clinical associations. Rheumatology. 2015;54:1194-9.

98. Suzuki S, Yonekawa T, Kuwana M, Hayashi YK, Okazaki Y, Kawaguchi Y, et al. Clinical and histological findings associated with autoantibodies detected by RNA immunoprecipitation in inflammatory myopathies. J Neuroimmunol. 2014;274:202-8.

99. Wang L, Liu L, Hao H, Gao F, Liu X, Wang Z, et al. Myopathy with antisignal recognition particle antibodies: clinical and histopathological features in Chinese patients. Neuromuscul Disord. 2014;24:335-41.

100. Ellis E, Ann Tan J, Lester S, Tucker G, Blumbergs P, Roberts-Thomson $\mathrm{P}$, et al. Necrotizing myopathy: clinicoserologic associations. Muscle Nerve. 2012:45:189-94.

101. Kao AH, Lacomis D, Lucas M, Fertig N, Oddis CV. Anti-signal recognition particle autoantibody in patients with and patients without idiopathic inflammatory myopathy. Arthritis Rheum. 2004;50:209-15.

102. Takada T, Hirakata M, Suwa A, Kaneko Y, Kuwana M, Ishihara T, et al. Clinical and histopathological features of myopathies in Japanese patients with anti-SRP autoantibodies. Mod Rheumatol. 2009;19:156-64.

103. Togawa R, Tanino Y, Nikaido T, Fukuhara N, Uematsu M, Misa K, et al. Three cases of interstitial pneumonia with anti-signal recognition particle antibody. Allergol Int. 2017;66:485-7.

104. Sugie $K$, Tonomura Y, Ueno $S$. Characterization of dermatomyositis with coexistence of anti-Jo-1 and anti-SRP antibodies. Intern Med. 2012;51:799-802.

105. Malkan A, Cappelen-Smith C, Beran R, Griffith N, Toong C, Wang M-X, et al. Anti-synthetase syndrome associated with anti PL-12 and antiSignal recognition particle antibodies and a necrotizing auto-immune myositis. J Clin Neurosci. 2015;22:396-8.

106. Benveniste O, Drouot L, Jouen F, Charuel J-L, Bloch-Queyrat C, Behin A, et al. Correlation of anti-signal recognition particle autoantibody levels with creatine kinase activity in patients with necrotizing myopathy. Arthritis Rheum. 2011;63:1961-71.

107. Christopher-Stine L, Casciola-Rosen LA, Hong G, Chung T, Corse AM, Mammen AL. A novel autoantibody recognizing 200-kd and 100-kd 
proteins is associated with an immune-mediated necrotizing myopathy. Arthritis Rheum. 2010;62:2757-66.

108. Alvarado-Cardenas M, Marin-Sánchez A, Martínez MA, Martínez-Martínez L, Pinal-Fernandez I, Labrador-Horrillo M, et al. Statin-associated autoimmune myopathy: a distinct new IFL pattern can increase the rate of HMGCR antibody detection by clinical laboratories. Autoimmun Rev. 2016;15:1161-6.

109. Palterer B, Cammelli D, Vitiello G, Giudizi MGMG, Cammelli D, Giudizi MGMG, et al. Anti-HMGCR and anti-DFS70 antibodies immunofluorescence patterns. Autoimmune Dis. 2017;16:321-2.

110. Musset L, Miyara M, Benveniste O, Charuel J-L, Shikhman A, Boyer $\mathrm{O}$, et al. Analysis of autoantibodies to 3-hydroxy-3-methylglutarylcoenzyme A reductase using different technologies. J Immunol Res 2014;2014:1-8.

111. Musset L, Allenbach $Y$, Benveniste O, Boyer O, Bossuyt X, Bentow $C$, et al. Anti-HMGCR antibodies as a biomarker for immune-mediated necrotizing myopathies: a history of statins and experience from a large international multi-center study. Autoimmun Rev. 2016;15:983-93.

112. Alshehri A, Choksi R, Bucelli R, Pestronk A. Myopathy with anti-HMGCR antibodies. Neurol Neuroimmunol Neuroinflamm. 2015;2:e124.

113. Keating P, Young J, George P, Florkowski C, Spellerberg M, Kennedy N. Anti-HMGCR autoantibodies in self-limiting statin-induced myopathy. Int J Rheum Dis. 2017;20:2179-81.

114. Kadoya M, Hida A, Hashimoto Maeda M, Taira K, Ikenaga C, Uchio N, et al. Cancer association as a risk factor for anti-HMGCR antibody-positive myopathy. Neurol Neuroimmunol Neuroinflamm. 2016;3:e290.

115. Mammen AL, Gaudet D, Brisson D, Christopher-Stine L, Lloyd TE, Leffell $M S$, et al. Increased frequency of DRB1*11:01 in anti-HMG-CoA reductase-associated autoimmune myopathy. Arthritis Care Res (Hoboken). 2012;64:1233-7.

116. Giudizi M, Cammelli D, Vivarelli E, Biagiotti R, Ferraro A, Bentow C, et al. Anti-HMGCR antibody-associated necrotizing myopathy: diagnosis and treatment illustrated using a case report. Scand J Rheumatol. 2016;45:427-9.

117. Tiniakou E, Pinal-Fernandez I, Lloyd TE, Albayda J, Paik J, Werner JL, et al. More severe disease and slower recovery in younger patients with anti-3-hydroxy-3-methylglutaryl-coenzyme A reductase-associated autoimmune myopathy. Rheumatology (Oxford). 2017;56:787-94.

118. Rider LG, Shah M, Mamyrova G, Huber AM, Rice MM, Targoff IN, et al. The myositis autoantibody phenotypes of the juvenile idiopathic inflammatory myopathies. Medicine (Baltimore). 2013;92:223-43.

119. Mahler M, Fritzler MJ. PM1-Alpha ELISA: the assay of choice for the detection of anti-PM/Scl autoantibodies? Autoimmun Rev. 2009:8:373-8

120. Jaskowski TD, Wilson A, Hill HR, Tebo AE. Diagnostic assays for Anti-PM/ Scl lgG antibodies: heterogeneity in antibody response or lack of standardization? Clin Chim Acta. 2011;412:1100-5.

121. Lega J-CC, Fabien N, Reynaud Q, Durieu I, Durupt SS, Dutertre M, et al. The clinical phenotype associated with myositis-specific and associated autoantibodies: a meta-analysis revisiting the so-called antisynthetase syndrome. Autoimmun Rev. 2014;13:883-91.

122. Mahler M, Raijmakers R. Novel aspects of autoantibodies to the PM/ Scl complex: clinical, genetic and diagnostic insights. Autoimmun Rev. 2007;6:432-7.

123. Muro Y, Hosono Y, Sugiura K, Ogawa Y, Mimori T, Akiyama M. Anti-PM/ Scl antibodies are found in Japanese patients with various systemic autoimmune conditions besides myositis and scleroderma. Arthritis Res Ther. 2015;17:57.

124. Aguila LA, Lopes MRU, Pretti FZ, Sampaio-Barros PD, Carlos De Souza $\mathrm{FH}$, Borba EF, et al. Clinical and laboratory features of overlap syndromes of idiopathic inflammatory myopathies associated with systemic lupus erythematosus, systemic sclerosis, or rheumatoid arthritis. Clin Rheumatol. 2014;33:1093-8.

125. Hanke K, Brückner CS, Dähnrich C, Huscher D, Komorowski L, Meyer W, et al. Antibodies against PM/SCl-75 and PM/SCl-100 are independent markers for different subsets of systemic sclerosis patients. Arthritis Res Ther. 2009;11:R22.

126. Schilders G, Egberts WV, Raijmakers R, Pruijn GJM. C1D is a major autoantibody target in patients with the polymyositis-scleroderma overlap syndrome. Arthritis Rheum. 2007;56:2449-54.
127. Migliorini P, Baldini C, Rocchi V, Bombardieri S. Anti-Sm and anti-RNP antibodies. Autoimmunity. 2005;38:47-54.

128. Lundberg I, Nennesmo I, Hedfors E. A clinical, serological, and histopathological study of myositis patients with and without anti-RNP antibodies. Semin Arthritis Rheum. 1992;22:127-38.

129. Coppo P, Clauvel JP, Bengoufa D, Oksenhendler E, Lacroix C, Lassoued K. Inflammatory myositis associated with anti-U1-small nuclear ribonucleoprotein antibodies: a subset of myositis associated with a favourable outcome. Rheumatology (Oxford). 2002;41:1040-6.

130. Craft J, Mimori T, Olsen TL, Hardin JA. The U2 small nuclear ribonucleoprotein particle as an autoantigen. Analysis with sera from patients with overlap syndromes. J Clin Invest. 1988;81:1716-24.

131. Kubo M, Ihn H, Kuwana M, Asano Y, Tamaki T, Yamane K, et al. Anti-U5 snRNP antibody as a possible serological marker for scleroderma-polymyositis overlap. Rheumatology (Oxford). 2002:41:531-4.

132. Sibilia J, Chatelus E, Meyer A, Gottenberg J-E, Sordet C, Goetz J. How can we diagnose and better understand inflammatory myopathies? The usefulness of auto-antibodies. Presse Med. 2010;39:1010-25.

133. Van Eenennaam H, Vogelzangs JHP, Bisschops L, Te Boome LCJ, Seelig HP, Renz M, et al. Autoantibodies against small nucleolar ribonucleoprotein complexes and their clinical associations. Clin Exp Immunol. 2002:130:532-40.

134. Peterson LK, Jaskowski TD, Mayes MD, Tebo AE. Detection of anti-U3RNP/fibrillarin lgG antibodies by line immunoblot assay has comparable clinical significance to immunoprecipitation testing in systemic sclerosis. Immunol Res. 2016:64:483-8.

135. Reimer G, Steen VD, Penning CA, Medsger TA, Tan EM. Correlates between autoantibodies to nucleolar antigens and clinical features in patients with systemic sclerosis (scleroderma). Arthritis Rheum. 1988;31:525-32.

136. Murata K-Y, Nakatani K, Yananeki M, Nakanishi I, Ito H. Anti-U3 ribonucleoprotein antibody-positive inflammatory myopathy: a case report. J Med Case Rep. 2016;10:169.

137. Tall F, Dechomet M, Riviere S, Cottin V, Ballot E, Tiev KP, et al. The clinical relevance of antifibrillarin (anti-U3-RNP) autoantibodies in systemic sclerosis. Scand J Immunol. 2017;85:73-9.

138. Tormey VJ, Bunn CC, Denton CP, Black CM. Anti-fibrillarin antibodies in systemic sclerosis. Rheumatology (Oxford). 2001;40:1157-62.

139. Belizna C, Henrion D, Beucher A, Lavigne C, Ghaali A, Lévesque H. AntiKu antibodies: clinical, genetic and diagnostic insights. Autoimmun Rev. 2010;9:691-4

140. Cooley HM, Melny BJ, Gleeson R, Greco T, Kay TW. Clinical and serological associations of anti-Ku antibody. J Rheumatol. 1999;26:563-7.

141. Mimori T, Hardin JA, Steitz JA. Characterization of the DNA-binding protein antigen Ku recognized by autoantibodies from patients with rheumatic disorders. J Biol Chem. 1986;261:2274-8.

142. Cavazzana I, Ceribelli A, Quinzanini M, Scarsi M, Airò P, Cattaneo R, et al. Prevalence and clinical associations of anti-Ku antibodies in systemic autoimmune diseases. Lupus. 2008;17:727-32.

143. Rigolet A, Musset L, Dubourg O, Maisonobe T, Grenier P, Charuel J-L, et al. Inflammatory myopathies with anti-Ku antibodies: a prognosis dependent on associated lung disease. Medicine (Baltimore). 2012;91:95-102.

144. Franceschini F, Cavazzana I. Anti-Ro/SSA and La/SSB antibodies. Autoimmunity. 2005:38:55-63.

145. PollockW, Toh BH. Routine immunofluorescence detection of Ro/SS-A autoantibody using HEp-2 cells transfected with human $60 \mathrm{kDa}$ Ro/ SS-A. J Clin Pathol. 1999;52:684-7.

146. Fritzler MJ, Hanson C, Miller J, Eystathioy T. Specificity of autoantibodies to SS-A/Ro on a transfected and overexpressed human $60 \mathrm{kDa}$ Ro autoantigen substrate. J Clin Lab Anal. 2002;16:103-8.

147. Dellavance A, Alvarenga RR, Rodrigues SSH, Barbosa SH, Camilo ACP, Shiguedomi HSO, et al. Autoantibodies to $60 \mathrm{kDa}$ SS-A/Ro yield a specific nuclear myriad discrete fine speckled immunofluorescence pattern. J Immunol Methods. 2013;390:35-40.

148. Defendenti C, Atzeni F, Spina MF, Grosso S, Cereda A, Guercilena G, et al. Clinical and laboratory aspects of Ro/SSA-52 autoantibodies. Autoimmun Rev. 2011;10:150-4.

149. Ghillani P, André C, Toly C, Rouquette AM, Bengoufa D, Nicaise P, et al. Clinical significance of anti-Ro52 (TRIM21) antibodies non-associated 
with anti-SSA $60 \mathrm{kDa}$ antibodies: results of a multicentric study. Autoimmun Rev. 2011;10:509-13.

150. Sonesson S-E, Hedlund M, Ambrosi A, Wahren-Herlenius M. Factors influencing fetal cardiac conduction in anti-Ro/SSA-positive pregnancies. Rheumatology (Oxford). 2017;56:1755-62.

151. Lloyd TE, Christopher-Stine L, Pinal-Fernandez I, Tiniakou E, Petri M, Baer A, et al. Cytosolic 5'-nucleotidase 1A As a target of circulating autoantibodies in autoimmune diseases. Arthritis Care Res (Hoboken). 2016:68:66-71.

152. Salajegheh M, Lam T, Greenberg SA. Autoantibodies against a $43 \mathrm{KDa}$ muscle protein in inclusion body myositis. PLoS ONE. 2011;6:e20266.

153. Pluk H, van Hoeve BJA, van Dooren SHJ, Stammen-Vogelzangs J, van der Heijden A, Schelhaas HJ, et al. Autoantibodies to cytosolic 5'-nucleotidase 1A in inclusion body myositis. Ann Neurol. 2013;73:397-407.

154. Kramp SL, Karayev D, Shen G, Metzger AL, Morris Rl, Karayev E, et al. Development and evaluation of a standardized ELISA for the determination of autoantibodies against CN-1A (Mup44, NT5C1A) in sporadic inclusion body myositis. Auto Immun highlights. 2016;7:16.

155. Greenberg SA. Cytoplasmic 5'-nucleotidase autoantibodies in inclusion body myositis: isotypes and diagnostic utility. Muscle Nerve. 2014;50:488-92.

156. Lilleker JB, Rietveld A, Pye SR, Mariampillai K, Benveniste O, Peeters MTJ, et al. Cytosolic 5'-nucleotidase $1 \mathrm{~A}$ autoantibody profile and clinical characteristics in inclusion body myositis. Ann Rheum Dis. 2017;76:862-8.

157. Herbert MK, Stammen-Vogelzangs J, Verbeek MM, Rietveld A, Lundberg IE, Chinoy $\mathrm{H}$, et al. Disease specificity of autoantibodies to cytosolic $5^{\prime}$-nucleotidase $1 \mathrm{~A}$ in sporadic inclusion body myositis versus known autoimmune diseases. Ann Rheum Dis. 2016;75:696-701.

158. Yeker RM, Pinal-Fernandez I, Kishi T, Pak K, Targoff IN, Miller FW, et al. Anti-NT5C1A autoantibodies are associated with more severe disease in patients with juvenile myositis. Ann Rheum Dis. 2018. https://doi. org/10.1136/annrheumdis-2017-212436.

159. Herbert MK, Pruijn GJM. Novel serology testing for sporadic inclusion body myositis: disease-specificity and diagnostic utility. Curr Opin Rheumatol. 2015;27:595-600.

160. Kaji K, Fertig N, Medsger TA, Satoh T, Hoshino K, Hamaguchi Y, et al. Autoantibodies to RuvBL1 and RuvBL2: a novel systemic sclerosisrelated antibody associated with diffuse cutaneous and skeletal muscle involvement. Arthritis Care Res. 2014;66:575-84.

161. Pauling JD, Salazar G, Lu H, Betteridge ZE, Assassi S, Mayes MD, et al. Presence of anti-eukaryotic initiation factor-2B, anti-RuvBL1/2 and anti-synthetase antibodies in patients with anti-nuclear antibody negative systemic sclerosis. Rheumatology. 2017. https://doi.org/10.1093/ rheumatology/kex458.

162. Takahashi T, Nakanishi T, Hamaguchi Y, Tanaka T, Fujimoto N. Case of anti-RuvBL1/2 antibody-positive morphea and polymyositis. J Dermatol. 2017:44:1188-90.

163. Satoh M, Langdon JJ, Chou C-H, McCauliffe DP, Treadwell EL, Ogasawara T, et al. Characterization of the Su antigen, a macromolecular complex of 100/102 and 200-kDa proteins recognized by autoantibodies in systemic rheumatic diseases. Clin Immunol Immunopathol. 1994;73:132-41.

164. Satoh M, Chan JYF, Ceribelli A, Vazquez del-Mercado M, EKL A. Autoantibodies to argonaute 2 (Su antigen). Adv Exp Med Biol. 2013;768:45-59.

165. Ogawa-Momohara M, Muro Y, Satoh M, Akiyama M. Autoantibodies to Su/Argonaute 2 in Japanese patients with inflammatory myopathy. Clin Chim Acta. 2017;471:304-7.

166. Bhanji RA, Eystathioy T, Chan EKL, Bloch DB, Fritzler MJ. Clinical and serological features of patients with autoantibodies to GW/P bodies. Clin Immunol. 2007;125:247-56.
167. Satoh M, Chan JYF, Ross SJ, Ceribelli A, Cavazzana I, Franceschini F, et al. Autoantibodies to survival of motor neuron complex in patients with polymyositis: immunoprecipitation of $D, E, F$, and $G$ proteins without other components of small nuclear ribonucleoproteins. Arthritis Rheum. 2011;63:1972-8.

168. Cobben JM, de Visser M, Scheffer H. From gene to disease; "survival" motor neuron protein and hereditary proximal spinal muscle atrophy. Ned Tijdschr Geneeskd. 2001;145:2525-7.

169. Enarson P, Rattner JB, Ou Y, Miyachi K, Horigome T, Fritzler MJ. Autoantigens of the nuclear pore complex. J Mol Med (Berl). 2004;82:423-33.

170. Nishio A, Water J, Leung PS, Joplin R, Neuberger JM, Lake J, et al. Comparative studies of antimitochondrial autoantibodies in sera and bile in primary biliary cirrhosis. Hepatology. 1997;25:1085-9.

171. Senécal J-L, Isabelle C, Fritzler MJ, Targoff IN, Goldstein R, Gagné M, et al. An autoimmune myositis-overlap syndrome associated with autoantibodies to nuclear pore complexes. Medicine (Baltimore). 2014;93:383-94.

172. Lleo A, Marzorati S, Anaya J-M, Gershwin ME. Primary biliary cholangitis: a comprehensive overview. Hepatol Int. 2017;11:485-99.

173. Maeda MH, Tsuji S, Shimizu J. Inflammatory myopathies associated with anti-mitochondrial antibodies. Brain. 2012;135(Pt 6):1767-77.

174. Konishi H, Fukuzawa K, Mori S, Satomi-Kobayashi S, Kiuchi K, Suzuki A, et al. Anti-mitochondrial M2 antibodies enhance the risk of supraventricular arrhythmias in patients with elevated hepatobiliary enzyme levels. Intern Med. 2017;56:1771-9.

175. Albayda J, Khan A, Casciola-Rosen L, Corse AM, Paik JJ, ChristopherStine L. Inflammatory myopathy associated with anti-mitochondrial antibodies: a distinct phenotype with cardiac involvement. Semin Arthritis Rheum. 2018;47:552-6.

176. Mauhin W, Mariampillai K, Allenbach Y, Charuel J-L, Musset L, Benveniste O. Anti-mitochondrial antibodies are not a hallmark of severity in idiopathic inflammatory myopathies. Joint Bone Spine. 2017. https://doi. org/10.1016/j.jbspin.2017.04.004.

177. Targoff IN, Arnett FC, Berman L, O'Brien C, Reichlin M. Anti-KJ: a new antibody associated with the syndrome of polymyositis and interstitial lung disease. J Clin Invest. 1989;84:162-72.

178. Gelpi C, Sontheimer EJ, Rodriguez-Sanchez JL. Autoantibodies against a serine tRNA-protein complex implicated in cotranslational selenocysteine insertion. Proc Natl Acad Sci USA. 1992;89:9739-43.

179. Casciola-Rosen LA, Pluta AF, Plotz PH, Cox AE, Morris S, Wigley FM, et al. The DNA mismatch repair enzyme PMS1 is a myositis-specific autoantigen. Arthritis Rheum. 2001:44:389-96.

180. Muro Y, Nakashima R, Hosono Y, Sugiura K, Mimori T, Akiyama M. Autoantibodies to DNA mismatch repair enzymes in polymyositis/dermatomyositis and other autoimmune diseases: a possible marker of favorable prognosis. Arthritis Rheumatol (Hoboken, NJ). 2014;66:3457-62.

181. Labrador-Horrillo M, Martínez MA, Selva-O'Callaghan A, Trallero-Araguás E, Grau-Junyent JM, Vilardell-Tarrés M, et al. Identification of a novel myositis-associated antibody directed against cortactin. Autoimmun Rev. 2014;13:1008-12.

182. Berrih-Aknin S. Cortactin: a new target in autoimmune myositis and myasthenia gravis. Autoimmun Rev. 2014;13:1001-2.

183. Albrecht I, Wick C, Hallgren Å, Tjärnlund A, Nagaraju K, Andrade F, et al. Development of autoantibodies against muscle-specific FHL1 in severe inflammatory myopathies. J Clin Invest. 2015;125:4612-24.

184. Amato AA, Griggs RC. Unicorns, dragons, polymyositis, and other mythological beasts. Neurology. 2003;61:288-9.

185. Tozzoli R, Villalta D, Bizzaro N. Challenges in the standardization of autoantibody testing: a comprehensive review. Clin Rev Allergy Immunol. 2017;53:68-77. 